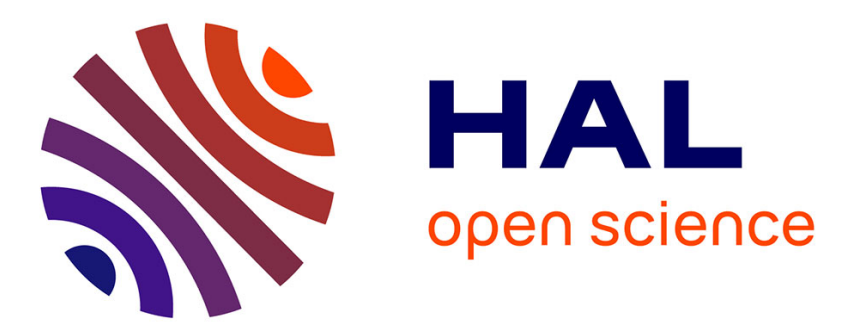

\title{
The La Bellière gold and antimony district (French Armorican Massif): a two-stage evolution model controlled by Variscan strike-slip tectonic
}

Florent Cheval-Garabédian, Michel Faure, Eric Marcoux, Jérôme Gouin, Maxime Picault

\section{To cite this version:}

Florent Cheval-Garabédian, Michel Faure, Eric Marcoux, Jérôme Gouin, Maxime Picault. The La Bellière gold and antimony district (French Armorican Massif): a two-stage evolution model controlled by Variscan strike-slip tectonic. Ore Geology Reviews, 2020, 125, 103681 (25 p.). 10.1016/j.oregeorev.2020.103681 . insu-02905083

\section{HAL Id: insu-02905083 \\ https://hal-insu.archives-ouvertes.fr/insu-02905083}

Submitted on 23 Jul 2020

HAL is a multi-disciplinary open access archive for the deposit and dissemination of scientific research documents, whether they are published or not. The documents may come from teaching and research institutions in France or abroad, or from public or private research centers.
L'archive ouverte pluridisciplinaire HAL, est destinée au dépôt et à la diffusion de documents scientifiques de niveau recherche, publiés ou non, émanant des établissements d'enseignement et de recherche français ou étrangers, des laboratoires publics ou privés. 


\section{Journal Pre-proofs}

The La Bellière gold and antimony district (French Armorican Massif): a twostage evolution model controlled by Variscan strike-slip tectonic

Florent Cheval-Garabédian, Michel Faure, Eric Marcoux, Jérome Gouin, Maxime Picault

PII:

DOI:

Reference:

To appear in:

Received Date:

Revised Date:

Accepted Date:
S0169-1368(20)30338-3

https://doi.org/10.1016/j.oregeorev.2020.103681

OREGEO 103681

Ore Geology Reviews

4 April 2020

6 July 2020

10 July 2020

Please cite this article as: F. Cheval-Garabédian, M. Faure, E. Marcoux, J. Gouin, M. Picault, The La Bellière gold and antimony district (French Armorican Massif): a two-stage evolution model controlled by Variscan strike-slip tectonic, Ore Geology Reviews (2020), doi: https://doi.org/10.1016/j.oregeorev.2020.103681

This is a PDF file of an article that has undergone enhancements after acceptance, such as the addition of a cover page and metadata, and formatting for readability, but it is not yet the definitive version of record. This version will undergo additional copyediting, typesetting and review before it is published in its final form, but we are providing this version to give early visibility of the article. Please note that, during the production process, errors may be discovered which could affect the content, and all legal disclaimers that apply to the journal pertain.

(C) 2020 Published by Elsevier B.V. 


\title{
The La Bellière gold and antimony district (French Armorican Massif): a two-stage evolution model controlled by Variscan strike-slip tectonic
}

Florent Cheval-Garabédian ${ }^{1-3^{*}}$, Michel Faure ${ }^{1}$, Eric Marcoux ${ }^{1}$, Jérome Gouin ${ }^{2}$, Maxime Picault ${ }^{2}$

1: Institut des Sciences de la Terre d'Orléans (ISTO), UMR 7327-CNRS/Université d'Orléans/BRGM, 1A Rue de la Férollerie 45071 Orléans Cedex 2, France

2: Variscan Mines, 10 rue Léonard-de-Vinci, 45074 Orléans Cedex 2

3: Present address: Société Minière Georges Montagnat, 30 route de la Baie des Dames, 98800

Nouméa, Nouvelle-Calédonie

* Corresponding author: florent-cg@hotmail.fr

\begin{abstract}
The La Bellière gold district, in the Ligerian domain of the Armorican Massif is the third one of France in term of production. It shows gold-bearing quartz veins neighboring with a complex network of Sb veins, hosted in the Neoproterozoic metasedimentary basement of the Mauges Nappe. New structural data, mineralogical, textural and geochemical assays have been carried out to clarify the gold and $\mathrm{Sb}$ veins relationships. Our results favor of two-step hydrothermal event with an early deep-seated gold event followed by a late shallower $\mathrm{Sb}$ event. The gold-bearing quartz veins are hosted by $\mathrm{N} 60^{\circ} \mathrm{E}$ to $\mathrm{N} 90^{\circ} \mathrm{E}$ sinistral strike-slip faults. These veins exhibit a four-stage paragenesis: 1) early barren quartz filling, 2) arsenopyrite-pyrite with minor scheelite assemblage, 3) gold and base metal sulfides crystallized after a ductile/brittle deformation stage, and 4) pyrite-carbonate coeval
\end{abstract}


with a late brittle stage. These results support a continuous evolution model from a deep emplacement level $(12$ to $9 \mathrm{~km})$ to a shallow one $(7$ to $<5 \mathrm{~km}$ ) with a brutal change in the $\mathrm{P} / \mathrm{T}$ conditions that triggered the deposition of gold (stage 2) controlled by a seismic-valve mechanism. On the contrary, $\mathrm{Sb}$ veins correspond to open space vein types, hosted in a $\mathrm{N} 20^{\circ} \mathrm{W}$ to $\mathrm{N} 20^{\circ} \mathrm{E}$ conjugated strike-slip fault network arranged in a Riedel shear model, controlled by $\mathrm{N} 130-140^{\circ} \mathrm{E}$ regional dextral strikeslip shear zone associated to the South Armorican Shear Zone system. A two-stage evolution is recognized, the first one consists of early pyrite-arsenopyrite with microcrystalline quartz, followed by a late stibnite stage formed after geodic quartz deposition. Quartz texture argues for a shallow emplacement $(<5 \mathrm{~km})$ of veins controlled by a suction-pump mechanism. Chronologically, the gold vein opening complies with a NE-SW maximum shortening direction different from the late-Variscan stress field responsible for the dextral Armorican shear zone during late Carboniferous, and constrains an indirect dating. Thus, a Visean age is proposed for the formation of gold veins. The overall features of gold deposits are close to those of mesozonal orogenic gold deposits in Europe. Conversely, Sbbearing veins are generated by a N-S shortening during the late Carboniferous. The Sb event, distinct in time from the earlier gold one, might correspond to a different expression of the so-called "epizonal" type in the orogenic gold model. It is proposed that the Late Carboniferous "Or 300" event is not the unique metallogenic period for gold deposition in the French Variscan domain. Our study highlights the role of the sinistral strike-slip shearing of possible Visean age, in the gold metallogenesis of the Ligerian domain.

Keywords. Orogenic gold; Sb mineralization; La Bellière district; Or300 hydrothermal event; Armorican Massif; Structural control; Variscan metallogeny 


\section{Introduction}

Gold and antimony (Sb) quartz vein-type deposits are recognized and mined since Antiquity in the European Variscan orogen. They are widespread in the Bohemian Massif (Nemec and Zacharias, 2018), Rhenish Massif, and Saxothuringian zone in Germany (Dill, 1985; Wagner and Cook, 2000), Iberian Massif (Gumiel and Arribas 1987; Neiva et al., 2008), French Massif Central and Armorican Massif (Périchaud 1980; Bril and Beaufort, 1989; Chauris and Marcoux, 1994; Bellot et al., 2003; Bouchot et al., 2005), Slovakian Western Carpathians (Chovan et al., 1995, 1998). Most of them were formed during the late and post-orogenic extensional phases of the orogeny. They display a clear structural control in relation to regional strike-slip and normal faults (Wagner and Cook 2000; Bellot et al., 2003; Bouchot et al., 2005; Neiva et al., 2008). Most of gold deposits can be classified as orogenic gold type deposits (Robert et al., 1997; Groves et al., 1998, 2003; Bierlein and Crowe, 2000; Goldfarb et al., 2005). However, some of them better fit with the intrusion-related gold deposit type (Zacharias et al., 2014). According to the same authors, the Variscan Sb deposits correspond to shallow quartz veins systems postdating the orogenic gold deposits.

The French Massif Central, which displays the most important gold reserves in France, has been studied since more than thirty years (e.g. Touray et al., 1989; Boiron et al., 1989, 1990, 2003; Bonnemaison and Marcoux, 1990; Bril et al., 1994; Marignac and Cuney, 1999; Charonnat et al., 1999; Essaraj et al., 2001; Nicaud, 2001; Bouchot et al. 2000, 2005; Chauvet et al., 2012). These authors interpreted the formation of gold and Sb-bearing veins as the result of a progressive evolution of a single hydrothermal event in which $\mathrm{Sb}$ was formed after the gold stage. In the Armorican Massif, the geological constraints on gold and $\mathrm{Sb}$ deposits are still rare, and restrained to the la Lucette $\mathrm{Sb}-\mathrm{Au}$ district (Serment, 1978), Le Semnon Sb-Au district (Pochon et al., 2018), and the Quimper Sb district (Fouquet 1980; Fig.1), all located in Central- and North-Armorican domains, and to the Vendée SbAu district (Marcoux et al., 1984; Bailly et al., 2000) in the South-Armorican domain. Gold and Sb 
deposits are considered to be formed during a large-scale hydrothermal event developed between 305$300 \mathrm{Ma}$ in the French Massif Central (Marignac and Cuney, 1999; Bouchot et al., 2000, 2005 and enclosed references), and around 360 Ma (Pochon et al., 2018) in the Central-Armorican Massif. In the Ligerian domain and South-Armorican Domain, the genetic process of gold and Sb deposition, and the understanding of the spatial association of these two elements remain poorly constrained. This study focusses on the La Bellière gold district, hosted in the Variscan Mauges Nappe of the Variscan Armorican Massif (Ballèvre et al., 2009; Figs. 1-2). This district shows a peculiar context with goldbearing quartz veins neighboring with a complex network of Sb veins. It represents the major gold district in the Armorican Massif according to its economic potential (Bouchot et al., 1997).

This paper presents the structural control of the gold and $\mathrm{Sb}$ quartz veins, the mineralogical and geochemical features that allow us to decipher relationships between gold and $\mathrm{Sb}$ mineralizations, and the veins formation mechanisms. Their paragenetic evolution, the nature of hydrothermal fluids responsible of the ore deposition, and their timing during the late stage of the Variscan orogeny are discussed.

\section{Regional geological background}

\subsection{The Armorican Massif}

With Iberian Massif, the Armorican Massif forms the westernmost part of the European Variscan belt that results from a continental collision between Gondwana and Laurussia plates during the late Devonian and Carboniferous. The Variscan orogeny ended during the late Carboniferous (Gzhelian) around 300 Ma (Matte, 1986; Faure et al., 2005; Ballèvre et al., 2009). From the geodynamic and paleogeographic points of view, the Armorican Massif (MA in the following) is subdivided from north to south into the Léon, North-, Central-, and South-Armorican domains that corresponds to four continental masses (Fig. 1, Faure et al., 2005, 2008; Ballèvre et al., 2009). The Nort-sur-Erdre fault that separates the last two domains represents the Devonian eo-Variscan suture. 
Furthermore, the MA is split by crustal-scale Late Carboniferous dextral strike-slip faults namely, the North, and South branches of the South Armorican Shear Zone, and the North Armorican Shear Zone (Jégouzo, 1980). The dextral motion of these crustal-scale strike-slip shear zones was coeval with the emplacement of late syntectonic plutons, like the Questembert granite dated at ca $316 \mathrm{Ma}$ (Ar-Ar on muscovite; Tartèse et al., 2011), or the Mortagne pluton (Cuney et al., 2001) formed by partial melting of metasediments (Tartèse and Boulvais, 2010).

\subsection{The Ligerian domain}

The Ligerian domain corresponds to the area located on both sides of the Nort-sur-Erdre eoVariscan suture (Fig. 2). South of the suture, it consists of a stack of Variscan nappes (Fig. 2, Marchand et al., 1969a and b; Cogné, 1974; Marchand et al., 1981; Lardeux and Cavet, 1994; Wyns et al., 1998a and b; Cartier and Faure, 2004; Faure et al., 2008; Ballèvre et al., 2009). From bottom to top, the following units are recognized. The Mauves-sur-Loire Unit consists of metagreywackes and metapelites metamorphosed under greenschist facies conditions. The overlying Champtoceaux Complex is a tectonic imbrication of paragneiss, orthogneiss with lenses of fine-grained eclogites frequently retrogressed into amphibolites, and migmatite (Marchand et al., 1981; Ballèvre et al. 2009). These foliated rocks experienced a high-pressure metamorphism well preserved in the mafic protoliths. Quartz-feldspar rich protoliths of the Champtoceaux Complex are commonly melted as migmatites (Faure et al., 2008; Pitra et al., 2010). Monazite from the migmatite that yields chemical $\mathrm{U}-\mathrm{Th}-\mathrm{Pb}$ age of $387 \pm 6 \mathrm{Ma}$, is interpreted as a result of the exhumation of high-pressure rocks (Cocherie et al. 2005), a second migmatitization event is also recorded between 340-330 Ma (Pitra et al., 2010). The overlying Drain Unit consists of mafic rocks (basalts, volcanoclastites, gabbros), ultramafic, and siliceous rocks. These rocks are interpreted as Variscan ophiolitic remnants. Conversely to the Champtoceaux complex, the rocks of the Drain Unit were metamorphosed under amphibolite facies conditions only. The uppermost unit, or Mauges Nappe, is formed by a 4-5 $\mathrm{km}$ thick Neoproterozoic greywacke and pelite series metamorphosed and foliated during the 
Neoproterozoic Cadomian orogeny. The Neoproterozoic rocks are unconformably overlain by a Cambrian to Ordovician sedimentary and volcanic series (Blaise et al. 1970; Wyns and Le Metour 1983; Wyns et al., 1998a and b). The Mauges Nappe is folded as an E-W regional antiform (Cogné, 1974).

The Nort-sur-Erdre suture was firstly reworked as a sinistral strike-slip fault that controlled the Tournaisian to Visean opening of the Ancenis pull-apart basin (Diot, 1980; Rolet, 1984; Lardeux and Cavet, 1994; Cartier and Faure, 2004). Moreover, this fault has been reactivated in a dextral motion during the Gzhelian (ex-Stephanian; Diot, 1980; Lemarchand et al.,2012). To the South, the south branch of the South Armorican Shear Zone is the southern boundary of the stack of nappes along which the Late Carboniferous two mica Mortagne granitic pluton emplaced (Jegouzo, 1980). Muscovite from the La Pommeraie leucogranite yields ${ }^{40} \mathrm{Ar} /{ }^{39} \mathrm{Ar}$ Visean ages at 337-336 Ma (located in Fig.2A; Gumiaux et al., 2004). The stack of nappes is folded in an E-W striking upright anticline, probably coeval with the dextral movement of the South Armorican Shear Zone (Bitri et al., 2003). The Late Carboniferous magmatism is also represented in this area by the Chemille two mica granite located in the eastern part of the Mauges Nappe and inferred of late Carboniferous age (Wyns and Hottin, 1992). Its western extension to the South of the Beaupréau town (Fig. 3A) is inferred by gravimetric anomaly (Martelet et al., 2009).

2.3 Geological setting of the La Bellière ore district

\subsubsection{Geology of the Mauges Nappe}

The La Bellière ore field (Fig. 3A) is hosted within an alternation of metagreywackes and metapelites belonging to the Mauges Nappe. The Neoproterozoic mafic volcanic and volcanicsedimentary rocks (called the Beaupréau formation), intercalated in the greywacke-pelite sedimentary series, form the southern boundary of the ore field. The Beaupréau formation geometrically overlies 
the metagreywacke from which it is separated by a graphite-rich black shale unit showing some iron cap covering some pyrite and pyrrhotite occurrences. The northern boundary of the ore field corresponds to the metapegmatite dyke field of La Boissière-sur-Evre supposed to be of Ordovician age (Wyns and Le Métour, 1983). In the ore district, the Cadomian regional foliation of the host rocks strikes $\mathrm{N} 80-120^{\circ} \mathrm{E}$, and dips 10 to $50^{\circ}$ to the south (Fig. 3B). Thus, these deposits lay on the southern limb of a N100E-N115E striking, km-sized late Variscan Mauges antiform. A crenulation lineation develops parallel to the antiform axis.

The Mauges Nappe experienced three metamorphic events. i) A greenschist facies one, well developed in the mafic volcanic Beaupréau formation, and also in the surrounding terrigenous rocks (south of St-Pierre-Montlimart). ii) It is overprinted to the W-NW by a medium pressure/medium temperature (MP/MT) event, characterized by staurolite, garnet, and locally kyanite. iii) Close to La Rouillère (Fig. 3), biotite and andalousite porphyroblasts, oblique to the regional Cadomian foliation, may represent a thermal contact metamorphism due to an underlying hidden granitic pluton, probably equivalent to the Chemillé leucogranite (Wyns, 1984). The greenschist facies metamorphism and the MP/MT assemblages (i) are related to the Cadomian event. The (ii) and (iii) events are related to the Variscan history (Wyns and Le Métour, 1983).

\subsubsection{The gold and Sb deposits of La Bellière district}

Gallic tribes, 2000 years BC, and the Romans already mined gold-bearing quartz veins in the Mauges region. From the end of the $\mathrm{XIX}^{\text {th }}$ to the end of the $\mathrm{XX}^{\text {th }}$ century, the La Bellière district was intensively explored, and successfully mined between 1905 and 1952 for gold. The La Bellière deposit, discovered in 1895, produced $10.32 \mathrm{t}$ of gold with an average grade of 9 to $10 \mathrm{~g} / \mathrm{t}$ Au (Bouchot et al., 1997 and enclosed references) from a complex quartz vein lode network extending more than 2 $\mathrm{km}$ in the WSW-ENE direction (Fig.3A-C). Between the middle of the seventies to the nineties the district was intermittently explored by the French Geological Survey (BRGM) and non-economic 
gold-shoots were discovered. Presently, the La Bellière gold district remains the most important one in the Armorican Massif, the third in term of metropolitan gold production, and presents the strongest economic potential for gold discovery in the Armorican Massif.

During previous works, two types of ore-bearing quartz veins have been identified: i) gold with sulfides, the most important one from an economic geology point of view, and ii) Sb veins (Wyns 1984; Braux et al., 1991; Bouchot, 1992). In the La Bellière gold field, about twenty gold-bearing quartz shear veins display a roughly triangular cartographic shape open to the east, extending about $15 \mathrm{~km}$ in the E-W direction, with an eastward widening from $3 \mathrm{~km}$ to $7 \mathrm{~km}$ in width (Fig. 3). Two main groups of $\mathrm{cm}$ - to $20 \mathrm{~m}$-thick gold-bearing quartz veins are recognized crosscutting the Neoproterozoic rocks of the Mauges Nappe, Le Petit Moulin and La Bellière group, to the north and La Rouillère and Bégrolle group to the south. These N60-90 ${ }^{\circ}$ E striking, steeply South dipping (60$80^{\circ}$ ) veins are discontinuously exposed (Fig. 3). The hydrothermal alteration (up to $20 \mathrm{~m}$ ) of the country-rock is characterized by bleaching, intense silicification, sericitization, and little sulfidation marked by pyrite dissemination (Wyns, 1984). Three main stages have been identified in the paragenetic sequence (Sevensma, 1942; Bouchot, 1992): (1) an early stage with massive arsenopyrite and minor pyrite, (2) an ore stage with galena, sphalerite, chalcopyrite, pyrrhotite and electrum, developed after a cataclastic episode, (3) a final barren stage. Two controversial structural models have been proposed to account for the gold-bearing quartz veins formation. Firstly, according to Wyns (1984), the gold-bearing quartz veins correspond to tension gashes opened during the activity of a N100-1 $10^{\circ} \mathrm{E}$ trending sinistral strike-slip fault in the Tournaisian-Visean. Secondly, Bouchot (1992) proposed a fault fill vein genesis under a sinistral shearing setting during the Late Carboniferous. According to the same authors, the source of the hydrothermal fluids would be related to a magmatic intrusion hidden under the ore field. However, a metamorphic fluid source has also been proposed (Boiron et al., 1990). 
Sb-bearing quartz veins are rarely exposed in the field, but numerous Sb-bearing float stones are widespread in the entire district (Fig. 3; Wyns, 1984, 1987). They display a N10 $\mathrm{W}$ to $\mathrm{N} 20^{\circ} \mathrm{E}$ strike with a steep dip, and less than $1 \mathrm{~m}$ thickness. The ore consists of massive stibnite with few arsenopyrite and pyrite associated with a black chalcedonic quartz. Presently, no genetic model for these Sb veins has been proposed, however Bouchot (1992) argued that the Sb quartz veins crosscut the gold ones.

\section{Sampling and analytical methods}

The geometry of the quartz veins has been assessed during our new geological mapping. Due to poor outcrop conditions, the presence of quartz veins is also inferred on the basis of float stones, and remains of mining works from Gallo-Roman times to the beginning of the $\mathrm{XX}^{\text {th }}$ century. The compilation of former descriptions, maps and exploration geochemical works (Mulot 1982; Wyns 1984; Bonnemaison and Boubée de Gramont 1985; Terree 1986; Wyns 1987; Blouin and Apolinarski 1990; Braux et al. 1991; Martel-Jantin 1996; Gouin et al., 2017) allowed us to set up an exhaustive state of art (Fig. 4).

Totally 105 quartz gangue and ore samples have been collected in the field. Gold-bearing quartz veins have been sampled in the different dumps and floats ( $60 \%$ of the sample), and $40 \%$ in fresh outcrops around La Bellière mine, Bégrolle, and Belleville (Fig.3A) occurrences. Barren quartz veins have been sampled in the La Barbinière and Rouillère veins (Fig.3A). Sb-bearing quartz samples come from the St-Antoine vein, la Bertinière area (Fig.3A), and the active Jousselin quarry near SaintPierre-Montlimart. For this study, 73 thin sections have been made for microscopic studies on ores and gangue minerals using a Leica DMRX polarizing optical microscope. The accessory mineral phases were identified using a Merlin compact Zeiss Scanning Electron Microscopy (SEM), cooperated by BRGM-CNRS-Orléans University, and equipped with Energy Dispersive System (EDS) for qualitative analysis. Chemical analyses of arsenopyrite were obtained with the Cameca SX-Five Electron Probe Micro-Analyzer (EPMA) at the Institut des Sciences de la Terre d'Orléans (ISTO). The sulfides analyses were performed using an accelerating voltage of $20 \mathrm{kv}$, a beam current at 40 
$\mathrm{nA}$, a beam diameter of $3 \mu \mathrm{m}$, and a counting time of $30 \mathrm{~s}$ for $\mathrm{Fe}, \mathrm{Ni}, \mathrm{Co}, \mathrm{Sb}, \mathrm{Pb}, \mathrm{Cu}, \mathrm{As}, \mathrm{Zn}, \mathrm{Ag}, \mathrm{Bi}$, and $60 \mathrm{~s}$ for gold (detection limit around $800 \mathrm{ppm}$ ). The gold grain analyses were performed using an accelerating voltage of $20 \mathrm{kv}$, a beam current at $60 \mathrm{nA}$, a beam diameter of $3 \mu \mathrm{m}$, and a counting time of $30 \mathrm{~s}$ for $\mathrm{Au}, \mathrm{Ag}, 60 \mathrm{~s}$ for $\mathrm{Bi}, \mathrm{Te}, \mathrm{Hg}, 120 \mathrm{~s}$ for $\mathrm{Cu}$ and $10 \mathrm{~s}$ for $\mathrm{Sb}$ and $\mathrm{S}$.

\section{Field and structural aspects}

4.1 The different vein families

The orientation of 155 structures, crosscutting the regional foliation of the Neoproterozoic country rocks, recognized in the field (60\% of personal observations), or interpreted form previous works (Fig. 4A-D), have been plotted on a rose-diagram (Fig.4B). Fig. 4C shows the structural data acquired on 17 outcropping quartz veins distributed all around the district. These data have been completed by a detail investigation in the Jousselin active quarry (Fig.4D-E), where well exposed quartz veins can be observed and measured. This last area offers the best outcropping conditions for kinematic determination and intersection relationships between the different vein families, and the regional fracturing (Fig.4D-E).

From the cartographic point of view, the mapped quartz veins (Fig. 4A-D) can be classified into four families according to their strikes (Fig. 4B-C-E): i) N60-90 ${ }^{\circ} \mathrm{E}$, ii) $\mathrm{N} 20^{\circ} \mathrm{W}$ to $\mathrm{N} 30^{\circ} \mathrm{E}$, iii) $\mathrm{N} 130$ $140^{\circ} \mathrm{E}$, and iv) $\mathrm{N} 90-120^{\circ} \mathrm{E}$. Each family presents distinct ore contents and quartz gangue textures that will be presented in the next section. The $\mathrm{N} 60-90^{\circ} \mathrm{E}$ and $\mathrm{N} 20^{\circ} \mathrm{W}$ to $\mathrm{N} 30^{\circ} \mathrm{E}$ families are associated respectively to gold deposits and $\mathrm{Sb}$ occurrences with a potential economic interest. On the contrary, the $\mathrm{N} 90-120^{\circ} \mathrm{E}$ family is barren. The $\mathrm{N} 130-140^{\circ} \mathrm{E}$ family is filled with black chalcedonic quartz with few pyrite aggregates.

\subsection{The $\mathrm{N} 60-90^{\circ} \mathrm{E}$ gold-bearing quartz veins}

Economic gold ore shoots are hosted within N60-90 ${ }^{\circ}$ E-striking, $60-80^{\circ} \mathrm{S}$-dipping, up to $0.5 \mathrm{~m}$ thick quartz veins (Fig.4) that represent opening jogs along shear zones. The infilling can be either massive 
or diffuse in the fault structure, and form meter-scale quartz vein or complex stockworks. These veins are filled by greasy white-grey quartz with a minor amount of white mica. Cataclastic textures are very common (Fig.5B), whereas banded textures are rarely observed.

One of these structures has been observed in the Jousselin quarry (West of St-Pierre-Montlimart town, Fig. 4A-D-E-F and Fig.5A). The gold-bearing quartz veins are hosted in a $15 \mathrm{~m}$ thick shear zone composed by altered and cataclased metagreywacke. This alteration consists of bleaching, silicification, and a neoformation of sericite, and sulfide (mostly pyrite). A 4 to $5 \mathrm{~m}$ thick zone with numerous greasy white-grey quartz veins develops in the center of the cataclastic zone. Altered metagreywacke clasts are cemented by the greasy white-grey quartz and black clay. Deformed quartz veins show lenticular shapes sub-parallel to the fault structure. In detail, the quartz veins dip is variable, close to the wall rock, it is steeply southward dipping $\left(\mathrm{ca} 80^{\circ} \mathrm{S}\right)$, while to the top of the structure, the dip becomes subvertical. A fracture cleavage is observed near the vein walls, the metagreywacke foliation tends to become parallel to the dip of the structure, and drag folds indicate a normal component. Fault surfaces show subhorizontal slickensides with a pitch of $05^{\circ}$ to the NE, quartz, and carbonate steps indicate a sinistral shear sense with a minor normal component that complies with previous work (Wyns 1984; Balé 1990). At macroscopic scale, the gold-bearing mineralization is characterized by deformed and anastomosed aggregates of sulfide veinlets. Arsenopyrite, pyrite, and to a lesser amount, galena, sphalerite and arsenopyrite are associated with mm-sized visible gold (Fig.5B).

\subsection{The $\mathrm{N}-20^{\circ} \mathrm{W}$ and $\mathrm{N} 10-30^{\circ} \mathrm{E}$ Sb-bearing quartz veins}

The $\mathrm{N} 10-20^{\circ} \mathrm{W}$ and $\mathrm{N} 10-30^{\circ} \mathrm{E}$ striking quartz veins have been grouped together because they present the same structural features (Fig.4D-E-F). They display either a veining morphology associated with fractured, and altered host rock corridor (Fig. 5C and Fig. 6 A and B). Compared to the gold-bearing veins, the $\mathrm{Sb}$ ones exhibit a smaller thickness, about 0.2 to $0.5 \mathrm{~m}$. Their main characteristics is a white or black chalcedonic quartz gangue (Fig.5D) with geodic or comb textures 
(Fig. 5D) that argue for a formation in a brittle setting (Vearncombe, 1993; Dong et al., 1995; Simmons et al., 2005). Comb quartz growing from the vein wall toward the center, and the geodic and fibro-radiated textures argue for an open-space vein filling of these veins. In the vicinity of the quartz veins, the country rock develops a hydrothermal alteration halo of about 10 meters thick (Wyns, 1984; Fig. 5C). Close to the vein, silicification is dominant, whereas the distal part of the alteration halo is formed by sericite, sulfides and red clays. In most cases, the N10-20 $\mathrm{W}$ striking quartz veins present a steep dip, between 65 to $85^{\circ}$ to the East, while the $\mathrm{N} 10-30^{\circ} \mathrm{E}$ veins display a steep dip to the west, like the $\mathrm{S}^{\mathrm{t}}$-Antoine vein (Fig.5C). Whatever the vein orientation, drag folds indicate a normal component of motion. The $\mathrm{N} 10-30^{\circ} \mathrm{E}$ slickensides with a $5^{\circ}$ dip to the $\mathrm{SW}$ document a sinistral motion with a minor normal component (Fig.6A). This kinematic pattern is in agreement with the cartographic offset of the $\mathrm{N} 60-90^{\circ} \mathrm{E}$ gold-bearing quartz veins by the $\mathrm{N} 10-30^{\circ} \mathrm{E}$ quartz veins and faults (Fig.4A). Furthermore, detail mapping document dextral motion along the N10-20 ${ }^{\circ} \mathrm{W}$ veins (Fig.4A-D). Sb mineralization occurs in both $\mathrm{N} 10-20^{\circ} \mathrm{W}$ and $\mathrm{N} 10-30^{\circ} \mathrm{E}$ striking quartz veins indicating that they formed in the same tectonic event. Thus Sb-bearing quartz veins were formed by open-space quartz vein filling mechanism controlled by strike-slip shearing. Sb develops as aggregates or acicular stibnite crystals disseminated in a black chalcedonic quartz gangue (Fig. 5D) that appears weakly mineralized. Arsenopyrite and euhedral acicular pyrite are associated to stibnite. White clay fills centimetric quartz vugs. Another type of quartz veins, close to the $\mathrm{N} 10-30^{\circ} \mathrm{E}$ have been observed in the Jousselin quarry (Fig.4D-E-F). It shows a N0-10 ${ }^{\circ}$ erientation with subvertical, or steeply dipping to the West, quartz comb tension gashes. They have a narrow thickness up to $5 \mathrm{~cm}$ without apparent offset of the wall rock. The infill is made by quartz comb with grain long direction perpendicular to the wall rock, and chalcedonic quartz with fibro-radiated quartz texture. They are rarely mineralized in acicular pyrite, however, $\mathrm{Sb}$ mineralization is absent. They do not postdate the Sb-bearing ones

\subsection{The $\mathrm{N} 130-140^{\circ} \mathrm{E}$ quartz veins and faults network}


The N130-140 ${ }^{\circ} \mathrm{E}$ direction is represented by two sets of structures. The first one consists of chalcedonic veins with geodic and comb quartz structures that display a 56-70 dip to the NE (Fig.4DE-F). Several veins are located in a 0.5 to $10 \mathrm{~m}$ thick fault corridor. The fault planes associated to these veins exhibit subhorizontal slickensides with a pitch of $5^{\circ} \mathrm{SE}$ that document a dextral sense of shear with a minor normal component (Fig.6B).

The second type of $\mathrm{N} 130-140^{\circ} \mathrm{E}$ structure is characterized by a pervasive fracture zone of 10 to 20 $\mathrm{m}$ thick (Fig.4D). This type of structure, only observed in the Jousselin quarry, is represented by a dense network of subvertical, NE trending joints with a 10 to $50 \mathrm{~cm}$ spacing. No kinematic indicator has been recognized, but on the basis of horizontal slickenside, a strike-slip displacement has been assumed by Wyns (1984).

\subsection{The $\mathrm{N} 85-50^{\circ} \mathrm{S}$ faults}

$\mathrm{N} 85-50^{\circ} \mathrm{S}$ faults, never described in previous works, have been observed in the Jousselin quarry (Fig.4D-E-F). They exhibit cataclasite and gouge clay, but no large quartz infill. Though rarely represented in the district, they have a large thickness (ca $1 \mathrm{~m}$ ). Drag folds show a reverse motion with a northward displacement of the upper part (Fig.6C).

\subsection{The $\mathrm{N} 90-120^{\circ} \mathrm{E}$ barren quartz veins}

This family is widely exposed in the field. It corresponds to the thickest quartz veins, larger than $1 \mathrm{~m}$, with field evidence of shearing. For instance, the La Barbinière vein (Fig.3A) is a N100E striking, $80^{\circ} \mathrm{S}$ dipping structure filled by milky massive white quartz in its core (Fig.6D). The vein walls display slickenlines dipping $10^{\circ}$ to the SE. Kinematic indicators show a sinistral strike-slip motion with a minor normal component. The entire shear structure, wider than $20 \mathrm{~m}$, exhibits an alteration halo with sericite and clay whereas the quartz vein margin is silicified. In contrast with the gold-bearing veins, only a few sulfides have been observed in this structure. The mineralization hosted in these shear veins is limited to pyrite and marcasite clusters disseminated in brecciated quartz. 


\section{Ore and gangue mineralogy}

\subsection{Gold-bearing quartz veins}

The La Bellière gold deposit formed throughout multistage deformations. On the basis of gangue and ore mineral textural observation, 4 mains depositional stages are recognized, namely: stage 1 with early quartz gangue (Fig.7A), and syntectonic deposition of scheelite, massive arsenopyrite (Fig.7B-E), and rare white micas; stage 2 with base metals and gold (Fig.8 A to G); stage 3 with illite and dolomite (Fig. $8 \mathrm{H}$ ); and stage 4 with pyrite, marcasite, and carbonates. The first stage is subdivided in stage 1A and stage 1B corresponding to the pre- and early-ore deposition.

Stage 1: early vein filling followed by shearing and scheelite-arsenopyrite paragenesis. Stage 1A corresponds to the initial quartz filling recorded only in some preserved parts of the vein. It is represented by weakly deformed, smoky, macrocrystalline quartz (Qz1) with abundant fluid inclusions, and weakly deformed plagioclase (Fig.7A).

During stage 1B, an heterogenous deformation episode affected the previous assemblage. The Qz1 grains experienced a dynamic recrystallization (Stipp et al., 2002) shown by undulose extinction, subgrain rotation recrystallization with golfed or jagged shape of the Qz1 boundary, bulging and quartz neograin (Qz2) formation at the expense of the early Qz1 (Figs.7A-B; 8C-E). The Qz2 displays undulose extinction and grain size reduction. Qz2 is located along 10 to more than $100 \mu \mathrm{m}$ shear bands that surround the edges of Qz1, or crosscut it. When Qz2 is well developed, it overprints the previous gangue leaving only relics of deformed Qz1 (Fig.7A-B). This deformation episode is coeval with deposition of massive arsenopyrite \pm pyrrhotite (Fig.7C). Arsenopyrite is the dominant sulfide of stage 1B. It shows cm-scale subeuhedral aggregates frequently associated with pyrite and muscovite. EPMA analysis of arsenopyrite does not indicate the presence of invisible gold but visible gold inclusions of 1-10 $\mu \mathrm{m}$ size are observed in arsenopyrite and pyrite crystals. This first gold occurrence is present as electrum with a mean of $27 \mathrm{wt} \% \mathrm{Ag}$ and $73 \mathrm{wt} \%$ gold $(\mathrm{n}=4)$. The silver content based on Morrison et al. (1991) shows a "medium gold fineness" of 728 (all data are reported 
in Appendix A.1). For the first time, large grains of subeuhedral scheelite and apatite (up to $2 \mathrm{~cm}$ ) have been found only close to Qz1, and plagioclase. Plagioclase alteration mainly observed by its transformation in iron dolomite occurred after the ductile/brittle deformation episode. This transformation is highlighted by relics of early plagioclase with polysynthetic twin included in ironbearing dolomite (Fig.7F).

Stage 2: main ore stage with gold and base metals deposition. At microscopic scale, this stage is characterized by intense microfracturing and brecciation of the Qz2 and ore formed during stage 1. Arsenopyrite and scheelite with sharp grain boundaries, are highly brecciated. Fractures are filled by a new quartz generation noted Qz3 (Fig.7C-H, G) that displays a weak deformation with limited undulose extinction of hyaline elongated or fibrous grains habitus, perpendicular to sulfides or scheelite clasts, and few fluids inclusions. Fibrous grains habitus display solid or liquid inclusion trails perpendicular to the walls of the veins (Fig.7H). Comb and hyaline quartz have also been observed rarely in the same fracture with sphalerite, galena and gold. Sphalerite, displaying pyrrhotite inclusions, and galena are the dominant sulfides coeval with gold deposition (Fig.8A-B-C). Sphalerite is also present as inclusions in other minerals crystallized during stage 2. Chalcopyrite is observed either alone in the fractured arsenopyrite (Fig.8C), or in ovoidal micro-inclusions scattered in sphalerite (Fig. 8D). Such a "chalcopyrite disease" texture formed by partial exsolution of sphalerite by chalcopyrite (Barton and Bethke, 1987). Traces of ullmanite (Fig.8F) and bismuth-tellurides (Fig.8G) have been observed as inclusions in galena and chalcopyrite. Two different types of Bi-Te have been recorded: i) a Bi-Te mineral close to hedleyite $\left(\mathrm{Bi}_{7} \mathrm{Te}_{3}\right)$ in chemical composition (Fig. 8G1), and ii) a $\mathrm{Bi}, \mathrm{Pb}$ and $\mathrm{Ag}$ sulfide (Fig. 8G2) that seems either close to the vikingite-gustavite series or belonging to native bismuth with contamination during EDS analysis by traces of $\mathrm{Pb}$ and Ag. In La Bellière vein, only a few traces of native bismuth have been observed (Picot et al. 1981), whereas traces of Bi-Te minerals are recognized in La Rouillère vein (Fig. 2). The presence of Bi-Te phases in the two main veins (La Rouillère and Bégrolle) supports the hypothesis of a structural link 
between these two veins (See Fig.3 for location). Chalcopyrite, pyrite, marcasite, and pyrrhotite are unfractured (Fig.7D, E and Fig8.A-B-C).

Gold is present as electrum (from $10 \mu \mathrm{m}$ to more than $1 \mathrm{~mm}$ in size) with a mean of $14 \mathrm{wt} \% \mathrm{Ag}$ and $86 \mathrm{wt} \%$ gold $(\mathrm{n}=17)$. The silver content is depleted compared to the first gold deposition during Stage 1B. Based on Morrison et al. (1991) electrum from the Stage 2 shows a "high gold fineness" of 860 (all data are reported in Appendix A.1). Electrum exhibits various associations : (i) trapped in the neoformed Qz2 quartz network (Fig.8E), (ii) between the deformed Qz1 quartz grains, (iii) inside neoformed quartz bands, (iv) frequent inclusions in galena, sphalerite (Fig.8A-B), and iron-dolomite, and (v) rarely present in pyrite and chalcopyrite (Fig.8C).

Iron-dolomite is commonly associated with stage 2 minerals (Fig.7D-E). It is characterized by euhedral crystals up to $100 \mu \mathrm{m}$ in size with numerous galena or electrum inclusions (Fig.8C). It constitutes up to $40 \mathrm{vol} \%$ of the gangue and has an average composition of $28.4 \mathrm{wt} \% \mathrm{MgO}, 11 \mathrm{wt} \%$ $\mathrm{CaO}, 15.6$ wt $\% \mathrm{FeO}$ and $1 \mathrm{wt} \% \mathrm{MnO}(\mathrm{n}=29)$. Analytical data on carbonates geochemistry are provided in Appendix A.2.

Stage 3: late opening stage. Brittle fracturing events postdating stage 2, were responsible for the brecciation of previous Qz2, sphalerite and galena. This fracturing represents the final brittle event coeval with filling of microcrystalline quartz (Qz4) associated with illite and low iron dolomite (18.3 wt $\% \mathrm{MgO}, 30.45 \mathrm{wt} \% \mathrm{CaO}, 5.7 \mathrm{wt} \% \mathrm{FeO}$ and $1.45 \mathrm{wt} \% \mathrm{MnO})$. It is also characterized by massive deposition of pyrite and marcasite from early pyrrhotite replacement.

Stage 4: late reopening stage. At least one late brittle reopening event is recorded after stage 3. It displays the same paragenesis as stage 3, with another generation of carbonate veinlets with subeuhedral pyrite crosscutting stage 3 assemblage.

The four stages described above are synthetized on figure 9, this evolution represent increments of a single progressive crystallization-deformation evolution.

\subsection{Sb-bearing-quartz veins}


The mineralogic and textural analysis of the La Bellière Sb veins allowed us to subdivide the paragenetic evolution into 4 stages, namely, stage 1: early silicification; stage 2: arsenopyrite-pyrite deposition; stage 3: main stibnite deposition; and stage 4: reopening of veins.

Stage 1: early silicification. This stage starts with brecciation of the country rocks, and deposition of microcrystalline quartz (Qz1) that cemented host-rock clasts (Fig.10A). Stage 1 is not well represented in our samples. Though available observations are limited, it seems that $\mathrm{Sb}$ was absent from this stage.

Stage 2: arsenopyrite-pyrite deposition. This stage corresponds to a large opening event of the vein, represented by the deposition of cm sized subhedral, undeformed comb quartz (Qz2) with fibroradiated texture. The initial microcrystalline Qz1 quartz acted as nucleus for the growth of the fibroradiated Qz2 quartz (Fig.10A-B), which is similar to the "flamboyant quartz texture" in the classification of Dong et al., (1995). Pyrite and marcasite are intimately associated in mixing and intergrowth with Qz2 deposition (Fig.10A-C). Their sharp shape and the porous surface suggest that they formed as pseudomorphs of previous pyrrhotite crystals (Picot and Johan, 1977; Bonnemaison and Marcoux, 1990; Epp et al., 2019). They are surrounded by euhedral rhombic arsenopyrite (Fig.10C). Isolated arsenopyrite crystals are present in the quartz gangue.

Stage 3: main stibnite deposition. This stage begins with quartz (Qz3) overgrowths on Qz2 comb quartz (Fig.10B-D). It is cloudier than Qz2, and displays golfed and corroded edge shapes (Fig. 10D). Massive stibnite is the main $\mathrm{Sb}$ ore mineral presents as: i) infilling voids formed during stage 2, ii) corroding the Qz2 grain boundaries, and iii) penetrating the Qz2 quartz comb texture (Fig.10B-D). Stibnite is present as aggregates or acicular shape that postdates arsenopyrite, and pyrite deposition (Fig.10E). Berthierite is frequently replaced by stibnite along fractures and grain boundaries (Fig.10F) with the neoformation of xenomorphic pyrite $(5-10 \mu \mathrm{m})$. Rare chalcopyrite inclusions are observed in berthierite (Fig.10F). Fuloppite and micro inclusions of native Sb $(2-5 \mu \mathrm{m})$ appear along stibnite cleavages (Fig.10G). Visible gold has never been observed in the Sb ore. 
Stage 4: reopening of veins. A late fracturing stage developed at the end of the mineralization history with the deposition of huge amount of marcasite and pyrite-marcasite upon stibnite pseudomorphs (Fig.10H). Sphalerite (Fig.10H) might belong to this stage.

The four stages described above are summarized on figure 11, this evolution represents increments of a single progressive crystallization-deformation evolution.

\section{Arsenopyrite chemistry and thermometry}

Chemical composition of La Bellière gold deposit arsenopyrite (stage 1) ranges from 43.69 to 44.82 wt \% As (31.01-31.93 at \% As), with Sb below the detection limit. Arsenopyrites from La Bellière district Sb occurrences (stage 2) display 36.03 to 41.36 wt \% As (26.48-29.89 At \% As), with $\mathrm{Sb}$ average content of $4.75 \mathrm{wt} \%$ (standard deviation $=1.71 \mathrm{wt} \% \mathrm{Sb}$ ). Arsenopyrite from Sb-bearing quartz veins in la Bellière district displays a distinct geochemical signature compared to gold-bearing quartz veins, characterized by an enrichment in $\mathrm{Sb}$. Sb-rich arsenopyrite is also described in other $\mathrm{Sb}$ vein-type deposit in the Central-Armorican domain (Fouquet, 1980; Pochon et al., 2018) and in the Massif Central (Sandras, 1988; Bellot et al., 2003).

Arsenopyrite crystallization temperatures can be calculated using the geothermometer of Kretschmar and Scott (1976). Considering that arsenopyrite is in equilibrium with pyrite, the calculated temperature is around $430{ }^{\circ} \mathrm{C}$ for the La Bellière stage 1 gold deposit, while the average temperature for the La Bellière Sb occurrences are below $300{ }^{\circ} \mathrm{C}$ (Table.1). From the Sb occurrences, more precise estimation may be considered with caution, because of the presence of $\mathrm{Sb}$ in the arsenopyrite. All analytical data are reported in Appendix A.3.

\section{Discussion and interpretation}

7.1 Structural controls of the gold and $\mathrm{Sb}$ deposition

The N60-90 ${ }^{\circ}$ sinistral strike slip fault-hosted gold-bearing quartz veins are controlled by ductile/brittle shearing, according to quartz gangue texture (Fig.7a, c). We note that the relative 
chronology between the gold-bearing-quartz vein and the $\mathrm{N} 90-\mathrm{N} 120^{\circ} \mathrm{E}$ barren ones have never been observed. However, on the basis of similar kinematics, ductile/brittle deformation record, and quartz textural characteristics of both veins, we assume that their emplacement occurred simultaneously.

Our detail mapping highlights the presence of the strike-slip N130-140 ${ }^{\circ}$ veins and faults (Fig. 10). Its fault orientations, kinematics, vein filling, mineralogy, deformation features are consistent with the regional faults that control the location of the Evre and La Bellière rivers (Fig.12A). The N130$140^{\circ} \mathrm{E}$ veins and faults display similar features with the $\mathrm{N} 20^{\circ} \mathrm{W}-\mathrm{N} 30^{\circ} \mathrm{E}$ Sb-bearing quartz, we assume that they can be related to the same tectonic event. Moreover, the cartographic offset of the $\mathrm{N} 60-90^{\circ} \mathrm{E}$ gold-bearing quartz veins (Fig. 12A) due to the $\mathrm{N} 20^{\circ} \mathrm{W}$ to $\mathrm{N} 30^{\circ} \mathrm{E}$ quartz veins and faults implies two independent tectonic events: i) an early gold event, and ii) a late $\mathrm{Sb}$ one.

The single-stage model proposed for the formation of the gold and $\mathrm{Sb}$ quartz veins cannot explain all the structural features of the entire ore district (Wyns, 1984). Our observations of highly sheared and recrystallized quartz aggregates (Qz1-Qz2), spatially associated with gold mineralization and barren $\mathrm{N} 90-120^{\circ} \mathrm{E}$ quartz veins are incompatible with a simple tensional opening of the veins, as proposed by Wyns, (1984). The marked difference in Sb-content of arsenopyrite supports also twostage emplacement (Fig.12B). The subhorizontal slickensides argue for a strike-slip regime, which is accommodated by a NE-SW maximum shortening direction (Z1-a). Thus, the Z1-a direction (Fig.12B) accounts for the development of the N60-90 ${ }^{\circ}$ E gold-bearing, and N90-120 $\mathrm{E}$ barren veins in sinistral shear zones.

The second deformation phase was characterized by an NNE-SSW maximum shortening direction (Z1-b in Fig.12B) compatible with formation of the $\mathrm{N} 20^{\circ} \mathrm{W}$ and $\mathrm{N} 30^{\circ} \mathrm{E}$ conjugate strike-slip faults associated with Sb-quartz vein, and chalcedonic quartz gangue. Furthermore, the N130-140 ${ }^{\circ} \mathrm{E}$ brittle dextral Evre fault complies with a Riedel model in which the Sb-bearing veins and fault correspond to the R and R' faults (Fig. 12B). In this model, the N20-10 ${ }^{\circ} \mathrm{W}$ quartz veins with $\mathrm{Sb}$ ore represent the synthetic R dextral faults. The $\mathrm{N} 10-35^{\circ} \mathrm{E}$ with $\mathrm{Sb}$ ore, like the St-Antoine vein correspond to the R' 
sinistral faults. The Riedel shear model would also account for the $\mathrm{N} 10^{\circ} \mathrm{E}$ chalcedonic, and geodic quartz with pyrite veins, observed in the Jousselin quarry that would correspond to tension gashes ( $\mathrm{T}$ type fracture; see Fig. 12B). The E-W striking reverse faults observed in the La Bellière mine (Fig. 3C), and in the Jousselin quarry (Fig. 6C) would correspond to the FI type structure (Fig. 12B). The FI structures cross cutting the gold-bearing quartz veins (Fig. 3C) confirm their formation after the gold-bearing event. In the current state of knowledge, this two-stage evolution model allows us to account for most of the veins, especially those with economic potential.

\subsection{Mineralogical evolution and emplacement model for the gold mineralization}

The gold-bearing quartz veins of the la Bellière district display a four-stage paragenesis (Fig.13). The first stage (1A) represents the early vein filling with minor amount of plagioclase with low-to null deformation. The crystallization temperature is assumed higher than $500{ }^{\circ} \mathrm{C}$ (Lang and Baker, 2001). Then, a ductile/brittle deformation stage 1B developed under an intermediate temperature, ca 400 to $500{ }^{\circ} \mathrm{C}$, resulted in the dynamic recrystallization of the Qz1 quartz (Stipp et al., 2002). The B1 stage was coeval with scheelite and massive arsenopyrite deposition with a discrete generation of electrum with medium silver content. This range of temperature emplacement is also supported by arsenopyrite geothermometry. A fluid inclusion study performed on Qz1 quartz confirms its high temperature formation, $\left(400{ }^{\circ} \mathrm{C}\right)$ under 200 to $150 \mathrm{MPa}$ (Boiron et al., 1990). Ductile/brittle deformation and high temperature of deposition argue for a deep-seated formation between 12 to 9 km (Scholz, 1988).

The transition from stages 1 to 2 (Fig.13) corresponds to another deformation characterized by grain-size micro fracturing of arsenopyrite or scheelite. The fracture-sealing by Qz3 that lacks of recrystallization texture argues for a shallower emplacement depth under a more brittle conditions compared to the stage 1 (Ramsay 1980; Cox, 1987; Cox et al., 1991). Quartz fibers and inclusions trails perpendicular to the vein walls are in favor of a crack-and-seal mechanism (Ramsay, 1980). 
The pressure and temperature drop from lithostatic (stage 1) to hydrostatic regime (stage 2) at the brittle-ductile transition can be interpreted as a consequence of a fault-valve mechanism (Sibson et al., 1988; Cox et al., 1991; Cox, 1995; Robert et al., 1995; Gaboury and Daigneault, 2000; Sibson, 2001). This mechanism might explain the deposition of gold with low silver content, during stage 2 under emplacement conditions at $200-300{ }^{\circ} \mathrm{C}$, and 7 to $<5 \mathrm{~km}$ depth, under hydrostatic regime (Scholz, 1988). This hypothesis is consistent with our structural analysis, which has demonstrated the synchronism between the fault activity and the formation of gold-bearing quartz vein. Generally, gold deposit models controlled by fault-valve behavior, have been set up for a compressional stress field (Sibson et al., 1988; Sibson, 2001; Gaboury and Daigneault, 2000; Robert et al., 1995; Groves et al., 1998). However, this kind of tectonic regime is not observed in the la Bellière district. A strike slip stress field, coeval with the genesis of orogenic gold deposits, may also be favorable for a fault-valve mechanism, as documented by Faleiros et al. (2014) on the orogenic gold deposit of Morro do Ouro (Brazil).

7.3 Mineralogical evolution and emplacement model for the $\mathrm{Sb}$ mineralization

The $\mathrm{N} 20^{\circ} \mathrm{W}-\mathrm{N} 30^{\circ} \mathrm{E}$ quartz veins, suggest an open-space quartz vein filling mechanism for their emplacement controlled by strike-slip faults motion. Deposition of microcrystalline quartz following country rocks fracturation, and deposition of comb and fibro-radiated quartz with arsenopyrite. The formation of the main Sb stage began with minor amount of berthierite and was followed by massive stibnite with minor native Sb (Fig.14). A late stage characterized by replacement of stibnite by pyritemarcasite and sphalerite corresponds to a low temperature one recorded in the Sb-bearing quartz veins in the Vendée district (Marcoux et al., 1984). It may be related to the $\mathrm{Pb}-\mathrm{Zn}$-Ba event, of Triassic age (ca 210-230 Ma), widely recognized in the Armorican Massif (Fouquet, 1980; Marcoux et al., 1984; Chauris and Marcoux, 1994). 
Comb, geodic, and fibro-radiated quartz textures, without deformation, are very similar to those observed in epithermal vein deposits formed between 50 to $1500 \mathrm{~m}$ depth at temperatures ranging from 100 to $300{ }^{\circ} \mathrm{C}$ (e.g. Dowling and Morison, 1988; White and Hedenquist, 1990; Dong et al., 1995; Kontak et al., 1996; Simmons et al. 2005; Chauvet et al. 2006; Shimizu 2014). In the La Bellière district, these textures suggest that $\mathrm{Sb}$ deposition took place at shallow crustal level, probably less than $2 \mathrm{~km}$ in brittle deformation conditions. The early microcrystalline quartz is interpreted as the result of crystallization from a siliceous gel during rapid drop in the fluid pressure (Bouchot et al., 1994). Fibro-radiated quartz texture corresponds to recrystallisation from early supersaturation of silica in the solution (Fournier, 1985; Dong et al., 1995). All these features, and the absence of ductilely deformed quartz grains, argue for an open-space vein infilling, as found in epithermal environments. To explain the genesis of $\mathrm{Sb}$ vein in such structural level and the vein formation mechanisms, we propose a model similar to the suction pump mechanism (Sibson, 1987).

\subsection{Timing of the gold and Sb ore deposition}

The NNE-SSW shortening direction (Z1-a) controlling the emplacement of la Bellière goldbearing quartz veins is incompatible with the dextral motion documented along South Branch of the South Armorican Shear Zone (SASZ, Jegouzo, 1980; Rollin and Colchen, 2001; Lemarchand et al. 2011). Moreover, in the southern part of the Armorican Massif, several lines of evidence support a sinistral strike-slip faulting developed earlier than the Late Carboniferous SASZ. Firstly, the neighboring Tournaisian-Visean Ancenis basin opened as a pull-apart controlled by the left-lateral reactivation of the Nort-sur-Erdre fault (Fig.2; Diot, 1980; Rolet, 1984; Cartier and Faure, 2004; Ducassou et al., 2011). Secondly, farther North, in the Lanvaux unit, the NW-SE striking sinistral shear zones were developed before the Late Carboniferous dextral shearing (Cogné et al. 1983; Faure and Cartier 1998). According to our structural control model, and the regional geological context, the La Bellière hydrothermal gold event would occur during the Visean, i.e. around 340-325 Ma. 
Presently, radiometric dating on $\mathrm{U}$, Th rich phases coeval with ore deposition are unavailable. Unfortunately, the analyzed scheelite, apatite, and carbonates minerals yield too much common lead, to be used to obtain valuable radiometric ages.

In the Massif Central, the late Variscan gold deposits were emplaced later under a relatively short period between 310-300 Ma, defining the so-called "Or-300 event" associated to a regional NW-SE extensional direction (Marignac and Cuney, 1999; Bouchot et al., 2005).

Moreover, at the Variscan orogeny scale, two separate gold deposition events were already recognized in the Bohemian Massif. The first gold event is well established at about 350-340 Ma by numerous Re-Os molybdenite ages (Zacharias and Stein, 2001; Zacharias et al., 2001, 2014 and Zacharias, 2016). 40Ar/39Ar dating on muscovite from the Jilové deposit (Zacharias et al., 2013) yield an age of $339 \pm 1.5$ Ma. The Sb-Au deposits (Krásná Hora and Příčovy deposits; Němec and Zachariáš, 2018) occurring in the same area, although not dated yet, clearly postdate lamprophyre dykes (minette) that intruded at $338 \pm 0.5 \mathrm{Ma}$ (40Ar/39Ar on biotite, Žák et al., 1997).

The second gold event is estimated to about 300-290 Ma, based on indirect geological evidence only, being represented mainly by the Ag-Au Roudný deposit (Zachariáš et al., 2004, 2009). This deposit differs markedly from the former group (350-340 Ma) with a highly $\mathrm{Sb}$ admixture in arsenopyrite (up to $4.2 \mathrm{wt} . \% \mathrm{Sb}$ ) and in absence of Bi-Te phases.

Based on the example of the gold mineralizations in the Bohemian massif, and our results in the La Bellière district, we can hypothesize that at least two gold deposition events might be present in the French Variscan massifs, namely an early event around 340-325 Ma, closely after the Variscan collision, and a second one, the "Or-300" event during the late-orogenic event.

On the contrary, the N-S shortening direction (Z1-b) controlling the development of Sb-bearing quartz veins complies with the dextral brittle motion along the South Armorican Shear Zone around 
310-300 Ma (Jegouzo, 1980; Rollin and Colchen, 2001; Lemarchand et al. 2011). This argues for an anti-clockwise rotation of the shortening direction during the late Carboniferous period at the scale of the Mauges Nappe. This two-stage model seems more efficient, at local scale, to explain the emplacement of the late Carboniferous mineralized quartz veins compared to reconstruction tectonic model of the Armorican Massif proposed by Gumiaux et al. (2004) predicting clockwise model with NNE-SSW shortening direction for the 310-300 Ma period.

A similar North-South shortening direction is also inferred in other Sb districts of the Armorican Massif. In the Vendée district (Marcoux et al., 1984), in La Lucette district, where Z1 strikes N05$10^{\circ} \mathrm{E}$ (Bouchot et al., 1997), and in Quimper district, the shortening direction is oriented $\mathrm{N} 30-20^{\circ} \mathrm{W}$ (Fouquet, 1980). The Sb veins crosscut the leucrogranite of Odet dated at $324 \pm 5 \mathrm{Ma}(\mathrm{U} / \mathrm{Pb}$ on zircon; Cocherie, 2001) and place relative time-constraints on this mineralizing event. Therefore, it might be assumed that most of the $\mathrm{Sb}$ deposits of the Armorican Massif were generated during the same tectonic event around 310-300 Ma. Numerous Sb deposits, widespread in the French Massif Central (Bouchot et al., 2005) or in the European Variscan belt, were also formed during this period (Bellot et al., 2003). In the Central-Armorican Domain, Le Semnon Sb-Au district seems to have been formed earlier, around $360 \mathrm{Ma}$ in local compressional regime (Pochon et al., 2018). The possibility of two Sb hydrothermal events successively developed around 360 and 300 Ma cannot be ruled out.

7.5 Genetic model and comparison with other Variscan deposits

\subsubsection{Gold deposits}

The gold-bearing quartz veins of La Bellière district show many similarities with deep-seated gold deposits of the Massif Central like the Saint-Yrieix or Salsigne districts (Touray et al., 1989; Bonnemaison and Marcoux, 1990; Boiron et al., 1989, 1990, 2003; Bril et al., 1994; Marignac and Cuney, 1999; Charonnat et al., 1999; Essaraj et al., 2001; Nicaud, 2001; Bouchot et al. 2000, 2005; Chauvet et al., 2012). It includes the dominant structural control with strike-slip, ductile/brittle shear 
zone developed in green-schist facies sedimentary rocks, and a late emplacement of economic ores with high fineness visible gold. They are also typical of mesozonal type in the orogenic gold deposit classification (Robert et al., 1997; Groves et al., 1998, 2003; Marignac and Cuney, 1999; Bierlein and Crowe, 2000; Goldfarb et al., 2001-2005; Bouchot et al. 2005).

The high $\mathrm{CO}_{2}$ and $\mathrm{CH}_{4}$ concentrations recorded in stage 1 fluids inclusions (Boiron et al., 1990), and high temperature $\left(400-500^{\circ} \mathrm{C}\right)$ coeval ductile/brittle deformation, suggest a deeply-sourced hydrothermal fluid. The limited presence of magmatic-source-elements related ore phases such as bismuth tellurides, wolframite, lollingite or molybdenite also suggests that the ore-forming fluids are not related to a pure magmatic process (Lang and Baker, 2001), but could possibly have a strong metamorphic origin. Another heat source must be found, and could be researched in the Champtoceaux metamorphic units. Indeed, the southern part of the Champtoceaux metamorphic units experienced a partial melting event coeval with the gold-deposits emplacement time. Champtoceaux migmatites were dated around 345-335 $\mathrm{Ma}\left({ }^{40} \mathrm{Ar} /{ }^{39} \mathrm{Ar}\right.$ on muscovite; Pitra et al., 2010), and its associated magmatic products, as the La Pommeraie leucogranite at $337-336 \mathrm{Ma}\left({ }^{40} \mathrm{Ar} /{ }^{39} \mathrm{Ar}\right.$ on muscovite; Gumiaux et al., 2004). This fertile geological context seems very similar to that established for the Saint-Yrieix gold-district in the Massif Central (Touray et al., 1989; Boiron et al., 1989, 1990, 2003; Marignac and Cuney, 1999; Essaraj et al., 2001; Nicaud, 2001; Bouchot et al. 2000, 2005), and could explain their metallogenic similarities, although their deposition events seem separated in time.

\subsubsection{Sb deposits}

The studied Sb-bearing quartz veins system would be 30-40 Ma younger than the orogenic gold deposit of La Bellière and belonging to a distinct hydrothermal event from gold one. In this model, it would be coeval with the regional high geothermal gradient, responsible for the South Armorican migmatite and leucogranite emplacement at the end of the post-collisional exhumation (e.g. Gapais et al., 1993; Brown and Dallmeyer, 1996; Turrillot et al., 2011; Ballouard et al., 2015). The shallow 
emplacement of the Sb quartz veins $(<5 \mathrm{~km})$ with a strong structural control and "epithermal" gangue textures could correspond to a different expression of "epizonal Au-Sb mineralization" $(<5 \mathrm{~km}, 130$ $300{ }^{\circ} \mathrm{C}$ ) in the classification of the orogenic gold deposits proposed by Groves et al. (1998).

Sb-bearing quartz veins of the La Bellière district are very similar to those of other districts in the Armorican Massif such as the Vendée or Quimper ones (Fig.1). This is also true with the late Variscan deposits in the Massif Central (Périchaud 1980; Bril and Beaufort, 1989; Munoz et al.,1992; Bril et al., 1994; Marignac and Cuney, 1999; Bellot et al., 2003), and in Western Europe (Chovan et al., 1998; Wagner and Cook, 2000; Neiva et al., 2008; Nemec and Zacharias, 2018). The Sb deposits might be ascribed to a common genetic model, but the source of the mineralizing fluid remains unknow. Due to the lack of volcanic activity during this period, lack of spatial and temporal links in the la Bellière district with the late Variscan leucogranite dykes, and the shallow crustal emplacement setting, pure magmatic fluids can be excluded.

The existence of two independent hydrothermal events associated to distinct geological contexts seems to be present in the La Bellière district with: i) an early gold-bearing one at $\sim 335 \mathrm{Ma}$ contemporaneous of the emplacement of the metamorphic and magmatic complex of Champtoceaux followed by ii) an $\mathrm{Sb}$ one at 310-300 Ma, in a more superficial emplacement condition, in relation with uplift of the basement and the hydrothermal system of the SBSASZ at this time (Lemarchand et al. 2011). Such a large time gap has not been reported in the main gold and Sb districts of the Massif Central (Saint-Yrieix, le Chatelet-Villeranges) where gold and Sb deposition are considered as parts of the same hydrothermal event (Touray et al., 1989; Boiron et al., 1989, 1990, 2003; Marignac and Cuney, 1999; Essaraj et al., 2001; Nicaud, 2001; Bouchot et al. 1997, 2000, 2005). Sb is commonly reported in several gold deposits with different accessory phases (Sb-bearing arsenopyrite, sulfosalts, stibnite...) as Laurieras deposit. In the Chatelet-Villeranges gold district, Sb may become predominant, Sb-ore corresponds to stibnite quartz-veins up to one-meter thickness. Introduction of 
the Sb-ore belong to the same hydrothermal event than gold-one around $300 \mathrm{Ma}$ and is considered later than the gold stage (Boiron et al., 1989).

\section{Conclusion}

The La Bellière district is the unique area in the Armorican Massif where the relationships between gold-bearing and Sb-bearing quartz veins can be documented.

The gold-bearing quartz veins are located along N60-90 ${ }^{\circ}$ E striking sinistral strike-slip shear zones, controlled by a NE-SW maximum shortening at 340-325 Ma. This deformation episode that occurred earlier than the dextral-strike slip motion along the SASZ, was very important for gold metallogenesis in the Ligerian domain. Fluid overpressure and associated decrease in temperature, from with early ductile/brittle transition towards a shallower depth ( 7 to $<5 \mathrm{~km}$ depth) and a more brittle context trigged gold and base metals precipitation. The La Bellière gold veins exhibit characteristic features of a mesozonal orogenic gold deposit, similar to other Late Variscan gold deposits in Europe. The structural control of the La Bellière gold deposit argues for an indirect Visean age of deposition, which must be assessed by radiogenic dating. It is proposed that at least two major gold emplacement periods are recorded in the French Variscan Massifs, i) an early one between 340-325 Ma after the Variscan metamorphic peak, and ii) a later, “Or-300”, event during the late-orogenic evolution.

$\mathrm{Sb}$ mineralization emplacement is separated in time from gold-bearing-quartz veins and formed at 310-300 Ma according to our interpretation of the regional strain patterns. Sb-bearing-quartz veins at the la Bellière district were developed in $\mathrm{N} 10-20^{\circ} \mathrm{W}$ and $\mathrm{N} 0-30^{\circ} \mathrm{E}$ conjugate strike-slip faults developed in a dextral $\mathrm{N} 130-140^{\circ} \mathrm{E}$ dextral Riedel shear model, controlled at the Ligerian domain by the SBSASZ which acted as crustal drains for the Sb-bearing fluids.

$\mathrm{Sb}$ Quartz texture argues for a deposition in open-space vein filling and shallow environment $(<5$ $\mathrm{km}$ ). This event might belong to the different expression of "epizonal Sb-Au mineralization". It displays the same features than those recognized in other late Variscan Sb deposits in Europe, formed at ca 310-300 Ma. It could belong to the "Or-300" event in the Armorican Massif. 
Our study provides new elements to better target the regional exploration of orogenic gold and $\mathrm{Sb}$ veins in the Armorican Massif. The study of Sb occurrences is a powerful tool to constrain the cartographic shape and continuity of gold ore shoots.

\section{Acknowledgements}

This work was funded by E-Mines and is a part of the exploration program of Variscan Mines SASU Company conducted on the La Bellière district with contribution from ANRT. The authors thank the two companies for their constant logistical, financial, and scientific supports. In particular, Michel Bonnemaison and Jack Testard are thanked for facilitating access and logistics in the SaintPierre License. The E-Mines team and the Variscan Mines SASU team. Gauthier Delmaere and Marie Bidault for field assistance and fruitful discussions. We also acknowledge the UMR ISTO laboratory (CNRS-Université d'Orléans-BRGM) for the analytical facilities and the help of the analytical team, Ida Di-Carlo for EPMA analyses, Laurent Bailly for SEM analyses, Sylvain Janiec and Jean-Gabriel Badin for thin sections, and Patricia Benoist for technical assistance.

\section{References}

Bailly, L., Bouchot, V., Bény, C., Milési, J.P., 2000. Fluid inclusion study of stibnite using infrared microscopy: an example from the Brouzils antimony deposit (Vendée, Armorican Massif, France). Econ. Geol. 95, 221-226.

Balé, P., 1990. Analyse structurale de sondages orientés (La Bellière). Rapp. BRGM, Orléans, 52 pp.

Ballèvre, M., Bosse, V., Ducassou, C., Pitra, P., 2009. Palaeozoic history of the Armorican Massif: Models for the tectonic evolution of the suture zones, C. R. Geoscience. 341,174-209.

Ballouard, C., Boulvais, P., Poujol, M., Gapais, D., Yamato, P., Tartèse, R., Cuney, M., 2015. Tectonic record, magmatic history and hydrothermal alteration in the Hercynian Guérande leucogranite, Armorican Massif, France. Lithos, 220$223,1-22$.

Barton, P.B., Bethke, Jr.P.M., 1987. Chalcopyrite disease in sphalerite: Pathology and epidemiology. American Mineralogist 72, 451-467.

Bellot, J.P., Lerouge, C., Bailly, L., Bouchot, V., 2003. The Biards Sb-Au-Bearing Shear Zone (Massif Central, France): An Indicator of Crustal-Scale Transcurrent Tectonics Guiding Late Variscan Collapse. Econ. Geol. 98, $1427-1447$.

Bierlein, F.P., Crowe, D.E., 2000. Phanerozoic orogenic lode gold deposits. Rev. Econ. Geol. 13, $103-139$. 
Bitri, A., Ballèvre, M., Brun, J-P., Chantraine, J., Gapais, D., Guennoc, P., Gumiaux, C., Truffert, C., 2003. Imagerie sismique de la zone de collision hercynienne dans le Sud-Est du Massif Armoricain (projet Armor 2/programme Géofrance 3D), 11 pp.

Blaise, J., Cavet, P., Lardeux, H., 1970. Les relations entre Brioverien et Paleozoique sur la rive gauche de la Loire entre Saint-Florent-le-Vieil et Chalonnes (Maine-et-Loire, sud-est du Massif Armoricain). Bull, Soc, géol, de France 1, $5-14$.

Blouin, J.P., Apolinarski, F., 1990. Le district aurifère de Saint-Pierre-Montlimart : travaux réalisés sur le PER de Gesté de 1987 à 1989. Rapp. BRGM, DAM/DL/Nantes, 124 pp.

Boiron, M.-C., Cathelineau, M., Trescases, J-J., 1989. Condition of gold-bearing arsenopyrite crystallization in the Villeranges Basin, Marche-Combrailles shear zone, France; a mineralogy and fluid inclusion study. Economic Geology 84, 1340-1362.

Boiron, M.C., Cathelineau, M., Dubessy, J., Bastoul, A.M., 1990. Fluids in Hercynian Au veins of from the French Variscan belt. Mineralogical Magazine 54, 231-243.

Boiron, M.C., Barakat, A., Cathelineau, M., Banks, D.A., Durisova, J., Moravek, P., 2001. Geometry and P-V-T-X conditions of microfissural ore fluid migration: the Mokrsko gold deposit (Bohemia). Chem. Geol. 173, 207-225.

Boiron, M.-C., Cathelineau, M., Banks, D.A., Fourcade, S., Vallance, J., 2003. Mixing of metamorphic and surficial fluids during the uplift of the Hercynian upper crust: consequences for gold deposition. Chem. Geol. 194, 119-141.

Bonnemaison, M., Boubée de Garmont, X., 1985. Résultats de mission du PER de Gesté, Rapp. BRGM, Orléans, 12 pp.

Bonnemaion, M., Marcoux, E., 1990. Auriferous mineralization in some shear-zones: A three-stage model of metallogenesis. Miner. Deposita 25, 96-104.

Bouchot, V., 1992. Les veines quartzeuses aurifères associées aux zones de cisaillement du gisement de la Bellière. Rapp. BRGM, R 35667, Orléans, 76 pp.

Bouchot, V., Gros, Y., Piantone, P., 1994. Dynamics of shallow late-Variscan gold mineralization: the Le Châtelet Auarsenopyrite quartz veins, Massif Central, France. Miner. Deposita 29, 461-473.

Bouchot, V., Milési, J.P., Lescuyer, J.L., Ledru, P., 1997. Les minéralisations aurifères de la France dans leur cadre géologique autour de 300 Ma: Chronique de la Recherche Minière 528, 13-62.

Bouchot, V., Milesi, J.P., and Ledru, P., 2000. Crustal-scale hydrothermal palaeofield and related Au, Sb, W orogenic deposits at 310-305 Ma (French Massif Central, Variscan belt): Society of Geology Applied to Ore Deposits SGA News, v. 10, 6-12.

Bouchot, V., Ledru, P., Lerouge, C., Lescuyer, J-L., Milesi, J-P., 2005. Late Variscan mineralizing systems related to orogenic processes: the French Massif Central. Ore Geol. Rev. 27, 169-197.

Braux, C., Apolinarski, F., Blouin, J-P., 1991. District aurifère de Saint-Pierre-Montlimart (Vendée - France). Synthèse des travaux d'exploration. Rapp. BRGM R32554, Orléans, 55 pp.

Bril, H., Beaufort, D., 1989. Hydrothermal alteration and fluid circulation related to W, Au, and $\mathrm{Sb}$ vein mineralizations, Haut-Allier, Massif Central, France: Econ. Geol. 84, 2237-2251.

Bril, H., Marignac, Ch., Cathelineau, M., Tollon, F., Cuney, M., Boiron, M.C., 1994. Metallogenesis of the French Massif Central: Time-space relationships between ore deposition and tectono-magmatic events. Pre-Mesozoic Geology in France and Related Areas, part III, 379-402. 
Brown, M., Dallmeyer, R.D., 1996. Rapid Variscan exhumation and the role of magma in core complex formation: southern Brittany metamorphic belt, France. Journal of Metamorphic Geology 14, 361-379.

Cartier, C., Faure, M., 2004. The Saint-Georges-sur-Loire olistostrome, a key zone to understand the Gondwana-Armorica boundary in the Variscan belt (Southern Brittany, France). Int. J Earth Sci. 9, 945-958.

Chantraine, J., Atran, A., Cavelier, C., 1996. Geological map of France, 1/1 000 000. BRGM, Orléans.

Charonnat, X., Chauvet, A., Faure, M., 1999. Structural control of the Late Hercynian Cevennes gold mineralizations, French Central Massif. CR Acad. Sci. Paris, 328, 463-469.

Chauris, L., Marcoux, E., 1994. Metallogeny of the Armorican Massif. Pre-cczoic Geology in France and Related Areas, $22 \mathrm{pp}$.

Chauvet, A., Bailly, L., André-Mayer, A-S., Monié, P., Cassard, D., Llosa Tajada, F., Vargas, J-R., Tuduri, Y., 2006. Internal vein texture and vein evolution of the epithermal Shila-Paula district, southern Peru. Miner. Deposita 41, $387-410$.

Chauvet, A., Volland-Tuduri, N., Lerouge, C., Bouchot, V., Monié, P., Charonnat, X., Faure, M., 2012. Geochronological and geochemical characterization of magmatic-hydrothermal events within the Southern Variscan external domain (Cévennes area, France). Int. J Earth Sci. 101, 69-86.

Chovan, M., Majzlan, J., Ragan, M., Siman, P., and Kristin, J., 1998, Pb-Sb and Pb-Sb-Bi sulfosalts and associated sulphides from Dubrava antimony deposit, Nizke Tatry Mts: Acta Geologica Universitatis Comenianae 53, 37-49.

Chovan, M., Hurai, V., Sachan, H.K., Kantor, J., 1995. Origin of the fluids associated with granodiorite-hosted Sb-AsAu-W mineralization at Dúbrava (Nízke-Tatry Mts, Western Carpathians). Miner. Deposita 30, 48-54.

Cocherie, A., 2001. Datations à la SHRIMP II des zircons magmatiques de l'Orthogneiss du Loc'h et du granite d'Odet dans le cadre du projet carte 1/50 000. Rapport interne BRGM AC/02.01, 8p.

Cocherie, A., Be Mezeme, E., Legendre, O., Fanning, C., Faure, M., Rossi, P., 2005. Electron microprobe dating as tool for determining the closure of Th-U-Pb systems in migmatitic monazites, American Mineralogist 90, 607-618.

Cogné, J., 1974. Le Massif Armoricain, Géologie de la France 1, 105-161.

Cogné, J-P., Choukroune, P., Cogné, J., 1983. Cisaillements varisques superposés dans le Massif de Lanvaux (Bretagne Centrale). CR Acad. Sci. Paris, 296, 773-777.

Cox, S.F., 1987. Antitaxial crack-seal vein microstructures and their relationships to displacement paths. J. Struct. Geol. 9, 79-787.

Cox, S.F., Wall, V.J., Etheridge, M.A., Potter, T.F., 1991. Deformation and metamorphic processes in the formation of mesothermal vein-hosted gold deposits, examples from the Lachlan Fold Belt in central Victoria Australia. Ore Geol. Rev. 6, 391-423.

Cox, S.F., 1995. Faulting processes at high fluid pressures: an example of fault valve behavior from the Wattle Gully Fault, Victoria Australia. J. Geophys. Res. 100, 12841-12859.

Cuney, M., Brouand, M., Stussi, J-M., 2001. Le magmatisme hercynien en Vendée. Corrélations avec le socle du Poitou et l'ouest du Massif central français. Géologie de la France 1-2, 117-142.

Dill, H.G., 1985. Antimoniferous mineralization from the Mid-European Saxothuringian Zone, mineralogy, geology, geochemistry and ensialic origin. Geologische Rundschau 74, 447-466. 
Diot, H., 1980. Recherches structurales dans la partie orientale du domaine Ligérien (Massif Armoricain). Unpuplished thesis, Nantes University, $147 \mathrm{pp}$.

Dong, G., Morrison, G., Jaireth, S., 1995. Quartz textures in epithermal veins, queensland-classification, origin and implication. Econ. Geol. 90, 1841-1856.

Dowling, K., Morison, G., 1988. Application of quartz textures to the classification of gold deposits using North Queensland examples. Econ. Geol. Monograph 6, 342-355.

Ducassou, C., Ballèvre, M., Lardeux, H., Robin, C., 2011. Evidence for pre-orogenic, Early Devonian rifting in the Variscan belt: stratigraphy and structure of the Paleozoic cover of the Mauges Unit (Upper Allochthon, Armorican massif, France). Int. J Earth Sci. 100, 1451-1475.

Epp, T., Walter, B. F., Scharrer, M., Lehmann, G., Henze, K., Heimgärtner, C., Bach, W., Markl, G., 2019. Quartz veins with associated $\mathrm{Sb}-\mathrm{Pb}-\mathrm{Ag} \pm \mathrm{Au}$ mineralization in the Schwarzwald, SW Germany: a record of metamorphic cooling, tectonic rifting, and element remobilization processes in the Variscan belt. Min. Deposita, 54, 281-306.

Essaraj, S., Boiron, M.-C., Cathelineau, M., Fourcade, S., 2001. Multistage deformation of Au-quartz veins (Lauriéras, French Massif Central): evidence for late gold introduction from microstructural, isotopic and fluid inclusion studies. Tectonophysics336, 79-99.

Faleiros, A. M., da Cruz Campanha, G. A., Faleiros, F. M., da Silveira Bello, R. M., 2014. Fluid regimes, fault-valve behavior and formation of gold-quartz veins-The Morro do Ouro Mine, Ribeira Belt, Brazil. Ore Geol. Rev. 56, $442-456$.

Faure, M., Cartier, C., 1998. Déformations ductiles polyphasées dans l'antiforme orthogneissique de St-Clément-de-laplace (unité de Lanvaux, Massif Armoricain). CR Acad. Sci. Paris, 326, 795-802.

Faure, M., Be Mézème, E., Duguet, M., Cartier, C., Talbot, J-Y., 2005. Paleozoic tectonic evolution of medio-Europa from the example of the French Massif Central and Massif Armorican. In: (eds.) Carosi, R., Dias, R., Iacopini, D., and Rosenbaum, G., The southern Variscan belt, Journal of the Virtual Explorer, Electronic Edition, ISSN 19, 14418142.

Faure, M., Bé Mézème, E., Cocherie, A., Rossi, P., Chemenda, A., Boutelier, D., 2008. Devonian geodynamic evolution of the Variscan Belt, insights from the French Massif Central and Massif Armorican, Tectonics 27, 1-19.

Fouquet, M., 1980. Les districts antimonifères de Quimper et du Cap Sizun (Finistere) leur place dans la métallogénie de I'antimoine dans le Massif Armoricain (France). Unpublished thesis, Clermont-Ferrand University, 212 pp.

Fournier, R.O., 1985. The behaviour of silica in hydrothermal solutions. Econ. Geol. Rev. 2, 45-62.

Gaboury, D., Daigneault, R., 2000. Flat vein formation in a transitional crustal setting by self-induced fluid pressure equilibrium, an example from the Géant Dormant gold mine Canada. Ore Geol. Rev. 17, 155-178.

Gapais, D., J.-L. Lagarde, C. Le Corre, C. Audren, P. Jégouzo, A. Casas Sainz, and J. Van Den Driessche, J, 1993), La zone de cisaillement de Quiberon: Témoin d'extension de la chaine Varisque en Bretagne méridionale au Carbonifère, C. R. Acad. Sci., 316, 1123-1129.

Goldfarb, R.J., Groves, D.I., Gardoll, S., 2001. Orogenic gold and geologic time; a global synthesis. Ore Geol. Rev. 18, $1-75$.

Goldfarb, R.J., Baker, T., Dubé, B., Groves, D.I., Hart, C.J.R., Gosselin, P., 2005. Distribution, character, and genesis of gold deposits in metamorphic terranes. Econ. Geol. 100th Anniversary 407-450. 
Gouin J, Fayol N, Lebret P, Picault M, Raoult G, Zimmermann M, Bonnemaison M, Testard J (2018) Rapport d'activité annuel 2017 PERM Saint-Pierre. Unpublished report from Variscan-Mines, VM-00085, 188 pp.

Groves, D.I., Goldfarb, R.J., Gebre-Mariam, M., Hagemann, S.G., Robert, F., 1998. Orogenic gold deposits—a proposed classification in the context of their crustal distribution and relationship to other gold deposit types. Ore Geol. Rev. $13,7-27$.

Groves, D.I., Goldfarb, R.J., Robert, F., Hart, C.J.R., 2003. Gold deposits in metamorphic belts: overview of current understanding, outstanding problems, future research, and exploration significance. Econ. Geol. 98, 1-29.

Gumiaux, C., Gapais, D., Brun, J-P., Chantraine, J., Ruffet, G., 2004. Tectonic history of the Hercynian Armorican Shear belt (Brittany, France). Geodin. Acta 17, 289-307.

Gumiel, P., Arribas, A., 1987. Antimony deposits in the Iberian Peninsula. Econ. Geol. 82, 1453-1463.

Jégouzo, P., 1980. The South Armorican shear zone, J. of Struct. Geol. 2, 39 pp.

Kim, Y-S., Peacock, D.C-P., Sanderson, D.J., 2002. Fault damage zones. Journal of structural Geology 26, 503-517.

Kontak, D.J., Horne, R.J., Smith, P.K., 1996. Hydrothermal characterization of the West Gore Sb-Au deposit, Meguma Terrane, Nova Scotia, Canada. Econ. Geol. 91, 1239-1262.

Kretschmar, U., Scott, S.D., 1976. Phase relations involving arsenopyrite in the system Fe-As-S and their application: The Canadian Mineralogist 14, 364-386.

Lang, J-R., baker, T., 2001. Intrusion related gold systems: the present level of understanding. Miner. Deposita 36, 477489.

Lardeux, H., Cavet, P., 1994. Paleozoic of the Ligerian Domain, Pre-Mesozoic Geology in France and Related Areas. IGCP-Projet 233, Part 2 B, 152-156 pp.

Lemarchand, J., Boulvais, P., Gaboriau, M., Boiron, M-C., Tartèse, R., Cokkinos, M., Bonnet, S., Jégouzo, P., 2011. Giant quartz vein formation and high-elevation meteoric fluid infiltration into the South Armorican Shear Zone: geological, fluid inclusion and stable isotope evidence. Journal of the Geological Society, London 168, 1-11.

Matte, P., 1986. La chaîne Varisque parmi les chaines Paléozoïques péri atlantiques modèle d'évolution et position des grands blocs continentaux au Permo-Carbonifère, Bull. Soc. géol. Fr. 2, 9-24.

Marchand, J., Perrin, J., Weecksteen, G., Forstier, F-H., Lasnier, B., 1969a. Carte géologique de la France à 1/50 000, feuille Vallet (482), BRGM, Orléans.

Marchand, J., Perrin, J., Weecksteen, G., Forstier, F-H., Lasnier, B., 1969b. Notice explicative, Carte géologique France (1/50 000), feuille Vallet (482), BRGM, Orléans, $11 \mathrm{pp}$.

Marchand J., 1981, Ecaillage d'un "mélange tectonique" profond: le complexe cristallophyllien de Champtoceaux (Bretagne Méridionale). C. R. Acad. Sci Paris 293:223-228.

Marcoux, E., Serment, R., Allon, A., 1984. Les gites d'antimoine de Vendée (Massif Armoricain, France Historique des recherches et synthèses métallogénique, Chronique de la Recherche Minière 476, 3-30.

Marignac, C., Cuney, M., 1999. Ore deposits of the French Massif Central: insight into the metallogenesis of the Variscan collision belt. Miner. Deposita 34, 472-504. 
Martel-Jantin, B., 1996. La Bellière - France. Exploration pour or par sondages carottés profonds. Quartier de SaintThomas - Saint-Pierre-Montlimart (PER de Montrevault). Rapp. BRGM N 2277, Orléans, 22 pp.

Martelet, G., Pajot, G., Debeglia, N., 2009. Nouvelle carte gravimétrique de la France ; RCGF09 -Réseau et Carte Gravimétrique de la France. Rapp. BRGM RP-57908-FR, Orléans, 26 pp.

Morrison, G W., Rose, W J., Jaireth, S., 1991. Geological and geochemical controls on the silver content (fineness) of gold in gold-silver deposits. Ore Geol. Rev. 6, 333-364.

Mulot, B., 1982. L'or des Mauges. Histoire et Archéologie au service de la recherche minière. Unpublished personal document, $211 \mathrm{pp}$.

Munoz, M., Courjault-Radé, P., Tollon, F., 1992. The massive stibnite veins of the French Palaeozoic basement: A metallogenic marker of late Variscan brittle extension: Terra Nova 4, 171-177.

Neiva, A.M.R., Andras, P., Ramos, J.M.F., 2008. Antimony quartz and antimony-gold quartz vein from northern Portugal. Ore Geol. Rev. 34, 533-546.

Němec, M., Zachariáš, J., 2018. The Krásná Hora, Milešov, and Př́íovy Sb-Au ore deposits, Bohemian Massif: mineralogy, fluid inclusions, and stable isotope constraints on the deposit formation. Miner. Deposita 53, 225-244.

Nicaud, J., 2001. Contrôle structural de la mise en place des minéralisations aurifères du district de Saint-Yrieix: analyse de la fracturation, étude des altérations hydrothermales, Unpublished thesis, Limoges University. 252 pp.

Périchaud, J.J., 1980. L'antimoine, ses minerais et ses gisements. Synthèse gîtologique sur les gisements du Massif Central français. Chronique de la Recherche Minière 456, 5-64.

Picot, P., Johan, Z., 1977. Atlas des minéraux métalliques. Mem BRGM nº0-1977. 397 p.

Picot, P., Ahmadzadeh, H., Vanhille, F., 1982. Utilisation de l'inventaire minéralogique des gîtes et de la carte des linéaments en prospection minière. Rapp. BRGM DGRST/79-07-1317, Orléans, 10 pp.

Pitra, P., Ballèvre, M., Ruffet, G., 2010. Inverted metamorphic field gradient towards a Variscan suture zone (Champtoceaux Complex, Armorican Massif, France). J. metamorphic Geol. 28, 183-208.

Pochon, A., Gloaguen, E., Branquet, Y., Poujol, M., Ruffet, G., Boiron, M-C., Boulvais, P., Gumiaux, C., Cagnard, F., Gouazou, F., Gapais, D., 2018. Variscan Sb-Au mineralization in Central Brittany (France): A new metallogenic model derived from the Le Semnon district. Ore Geol. Rev. 97, 109-142.

Ramsay, J.G., 1980. The crack-seal mechanism of rock deformation. Nature 284, 135-139.

Robert, F., Boullier, A.M., Firdaous, K., 1995. Gold-quartz veins in metamorphic terranes and their bearing on the role of fluids in faulting. J. Geophys. Res. 100, 12841-12859.

Robert, F., Poulsen, K.H., Dubé, B., 1997. Gold deposits and their geological classification. Exploration Geochemistry $29,209-220$.

Rolet, J., 1984. Grabens losangiques (pull-appart) en régime de décrochement. Le rôle des coulissements hercyniens dans l’individualisation des bassins carbonifères du Massif armoricain. An. Soc. Géol. Nord 103, 209-220.

Rolin, P., Colchen, M., 2001. Les cisaillements varisques de la Vendée au Limousin. Géologie de la France, 1-2, 87-116.

Sandras, A., 1988. Les structures auro-antimonifères du district de Brioude-Massiac. Gîtologie et métallogénie des concentrations aurifères, Unpublished thesis, Nancy University. 211 pp. 
Scholz, C. H. (1988). The brittle-plastic transition and the depth of seismic faulting. Geologische Rundschau, 77(1), 319328.

Serment, R., 1978. La mine d'antimoine et or de La Lucette (Mayenne, France), Chronique de la Recherche Minière 442, $35-42$.

Sevensma, M.P., 1942. Gisement d'or de la Bellière. Revue de l'industrie Minérale 462, 10 pp.

Shimizu, T., 2014. Reinterpretation of the quartz textures in terms of hydrothermal fluid evolution at the Koryu Au-Ag deposit, Japan. Econ. Geol. 109, 2051-2065.

Sibson, R.H., 1987. Earthquake rupturing as a hydrothermal mineralizing agent. Geology 15, 701-704.

Sibson, R.H., Robert, F., Poulsen, K.H., 1988. High-angle reverse faults, fluid pressure cycling, and mesothermal goldquartz deposits. Geology 16, 551-555.

Sibson, R.H., 2001. Seismogenic framework for hydrothermal transport and ore deposition. Rev. Econ. Geol. 14, 25-50.

Simmons, S.F., White, C.N., John, D.A., 2005. Geological characteristics of Epithermal precious and base metal deposits. Economic Geology $100^{\text {th }}$ Anniversary 485-522 pp.

Stipp, M., Stünitz, H., Heilbronner, R., Schmid, S.M., 2002. The eastern Tonale fault zone: a 'natural laboratory' for crystal plastic deformation of quartz over a temperature range from 250 to $700{ }^{\circ} \mathrm{C}$. Journal of Structural Geology 24, 1861-1884.

Tartèse, R., Boulvais, P., 2010. Differentiation of peraluminous leucogranites 'en route' to the surface. Lithos 114, 353368.

Tartèse, R., Ruffet, G., Poujol, M., Boulvais, P., and Ireland, T.R., 2011. Simultaneous resetting of the muscovite K-Ar and monazite U-Pb geochronometers: A story of fluids: Terra Nova, v. 23, 390-398.

Terree, P., 1986. SNEAP-BRGM, PER de Gesté (La Bellière) convention №580, Rapport final. Unpublished report, BRGM, 482-483 28-C4, Orléans, 47 pp.

Touray, J.C., Marcoux, E., Hubert, P., Proust, D., 1989. Hydrothermal processes and ore-forming fluids in the Le Bourneix gold deposit, Massif Central France. Econ. Geol. 84, 1328-1339.

Turrillot P., Augier R., Monié P., Faure M. 2011. Late orogenic exhumation of the Variscan high-grade units (South Armorican Domain, western France), combined structural and 40Ar/39Ar constraints. Tectonics, 30, TC5007, doi : 10.1029/2010TC002788.

Vearncombe, J-R., 1993. Quartz vein morphology and implications for formation depth and classification of archaean gold-vein deposits. Ore Geol. Rev. 8, 407-424.

Wagner, T., Cook, N.J., 2000. Late-Variscan antimony mineralization in the Rheinisches Schiefergebirge, NW: evidence for stibnite precipitation by drastic cooling of high temperature fluid systems. Miner. Deposita 35, 206-222.

White, N.C., Hedenquist, J.W., 1990, Epithermal environments and styles of mineralization: Variations and their causes, and guidelines for exploration: Journal of Geochemical Exploration 36, 445-474.

Wilcox, R.E., Harding, T.p., Seely, D.R., 1973. Basic wrench tectonics. The American Association of Petroleum Geologists Bulletin 57, 74-96. 
Wyns, R., Le Metour, J., 1983. Le Précambrien du Massif vendéen. Etude détaillée de deux coupes de référence (coupe de l'Evre et coupe de la Divate) et synthèse des données récentes. Doc. BRGM 68, Orléans, 58 pp.

Wyns, R., 1984. Etude géologique du champ filonien de la Bellière dans le périmètre du P.E.R de Gesté. Rapp. BRGM 84 SGN 221 GEO, Orléans, 70 pp.

Wyns, R., 1987. Découverte de nouveaux indices minéralisés (Au, Sb) au SE de Chaudron en Mauges (Maine et Loire). Note BRGM 87 DAM 04820483 28D9, Orléans, 2 pp.

Wyns, R., Hottin, A-M., 1992. Etude géologique préliminaire du granite de la Chapelle-Rousselin (Maine-et-Loire. Rapp. BRGM 82-SGN-034-GEO, Orléans, 28 pp.

Wyns, R., Clément, J-P., Ballèvre, M., Moguedet, G., Biagi, R., Lardeux, H., Gruet, M., 1998a. Carte géologique de la France à $1 / 50$ 000, feuille Chemillé (483), Orléans.

Wyns, R., Lardeux, H., Moguedet, G., Duermael, G., Gruet, M., Biagi, R., 1998b. Notice explicative carte géologique France (1/50 000), feuille Chemillé (483), BRGM, Orléans, 72 pp.

Zachariáš, J., Stein, H., 2001. Re-Os ages of Variscan hydrothermal gold mineralizations, Central Bohemian metallogenetic zone. In: Piestrzyński A et al. (eds) Mineral Deposits at the Beginning of the 21st Century. Swets \& Zeitlinger Publishers Lisse, pp 851-854.

Zachariáš, J., Pertold, Z., Pudilová, M., Žák, K., Pertoldová, J., Stein, H., Markey, R., 2001. Geology and genesis of Variscan porphyry-style gold mineralization, Petráčkova hora deposit, Bohemian Massif, Czech Republic. Miner. Deposita 36: 517-541.

Zachariáš, J., Frýda, J., Paterová, B., \& Mihaljevič, M. (2004). Arsenopyrite and As-bearing pyrite from the Roudný deposit, Bohemian Massif. Mineralogical Magazine, 68(01), 31-46. Zachariáš, J., Paterová, B., Pudilová, M., 2009. Mineralogy, Fluid Inclusion, and Stable Isotope Constraints on the Genesis of the Roudny Au-Ag Deposit, Bohemian Massif. Econ. Geol. 104, 53-72.

Zachariáš, J., Žák, K., Pudilová, M., Snee, L. W., 2013. Multiple fluid sources/pathways and severe thermal gradients during formation of the Jílové orogenic gold deposit, Bohemian Massif, Czech Republic. Ore Geol. Rev. 54, 81109.

Zachariáš, J., Morávek, P., Gadas, P., Pertoldová, J., 2014. The Mokrsko-West gold deposit, Bohemian Massif, Czech Republic: mineralogy, deposit setting and classification. Ore Geol. Rev. 58: 238-263.

Zachariáš, J., 2016. Structural evolution of the Mokrsko-West, Mokrsko-East and Čelina gold deposits, Bohemian Massif, Czech Republic: role of fluid overpressure. Ore Geol. Rev. 74: 170-195.

Žák, K., Vlašímský, P., Snee, L.W., 1997. 40Ar/39Ar cooling ages of selected rocks of the Př́ibram ore region and the question of timing of sulfidic hydrothermal mineralization. Zprávy o geologických výzkumech v roce 1997 (Research in Geosciences in 1997). 172-173. (In Czech with English summary) 


\section{Figure Captions}

Fig. 1. Simplified geological map of the Armorican Massif (modified from Chantraine et al., 1996) with the location of Sb and gold occurrences and deposits (modified from Chauris and Marcoux, 1994). NASZ: North-Armorican Shear Zone; SASZ (N) and SASZ (S): northern and southern branches of the South-Armorican Shear Zone, respectively; NSEF: Nortsur-Erdre Fault; A: Lopérec district; B: Quimper district; C: La Lucette district; D: Le Semnon district; E: La Bellière district; F: Vendée district. Sb: stibnite; Au: gold; Cin: cinnabar; Gn: galena; Sp; sphalerite.

Fig. 2. (A) Geological and structural map of the Ligerian domain with location of the study area (Fig. 3). P: La Pommeraie 2 micas granite, C: Chemillé 2 micas granite. Modified after Cartier and Faure, (2004). (B) NW-SE cross section of the Ligerian domain showing the structural relationships between the North-and-Central Armorican Domain and the SouthArmorican Domain. The Mauges Nappe is the uppermost tectonic unit in the South-Armorican nappe stack. Modified after Cartier and Faure, (2004).

Fig.3. (A) Local geological map of the la Bellière district in the Mauges Nappe with the main gold and $\mathrm{Sb}$ veins and occurrences (modified from Wyns et al., 1998a,1998b). (B) Stereogram (lower hemisphere projection) of the poles of the regional foliation $(\mathrm{Fo})$ in the Neoproterozoic alternation of metagraywacke and metapelite with the density contours per $1 \%$ area, n: number of measurements. (C) North-South cross section across the la Bellière deposit showing the geometry of the gold-bearing quartz vein, and the late faults crosscutting the gold mineralization (modified from Sevensma, 1942).

Fig.4. (A) Structural map with the main veins and faults of the la Bellière district classified on the basis of their metal content and quartz type infilling, (personal field observations correspond to $60 \%$ of mapped structures and compilation of historical data: Blouin and Apolinarski, 1990; Braux et al., 1991; Mulot, 1982; Wyns, 1984; Bonnemaison and Boubée de Gramont, 1985; Wyns, 1987; Terree, 1986; Martel-Jantin, 1996). The fault kinematics are inferred from field observations and cartographic offsets of mineralized structures faults or quartz veins. See text for discussion. (B) Rose diagram of the mineralized quartz veins orientations observed on the field and inferred from previous works. Four orientation families of mineralized and barren veins and faults have been recognized. (C) Stereogram (lower hemisphere projection) of poles of mineralized and barren quartz veins measured in the field. (D) Detailed structural map of the Jousselin quarry in the la Bellière district with orientation dip, quartz and ores infilling. (E) Stereogram (lower hemisphere projection) of poles of faults, and quartz veins with ore infilling, 40 structures have been measured on the field and 15 come from Wyns, (1984). (F) Stereogram (lower hemisphere projection) showing great circle and related kinematics of 
the different quartz veins and faults. Number of faults and veins measured with clear kinematics indicators $=12$. See text for discussion about the kinematics.

Fig.5. Field and hand sample pictures of gold and Sb-bearing structures. (A) Gold-bearing lenticular quartz veins in a $\mathrm{N} 65^{\circ} \mathrm{E}$ striking shear zone with hydrothermalized Neoproterozoic country rocks in the Jousselin quarry. Quartz veins contain traces of pyrite, galena, chalcopyrite and sphalerite. Kinematic indicators show a sinistral strike-slip fault with a normal component. (B) Representative ore sample of the la Bellière gold deposit, with sphalerite (Sp), galena (Gn), visible gold, and carbonates in a grey-white sheared quartz. Sample from dumps of Bonair shaft. (C) Sb-bearing chalcedonic and comb quartz vein oriented $\mathrm{N} 25^{\circ} \mathrm{E}$ with stibnite and pyrite crosscutting the hydrothermalized Neoproterozoic country rock (St-Antoine vein). (D) Representative ore sample of an Sb-bearing quartz vein showing chalcedonic black quartz with dissemination of stibnite and pyrite. Sample from $\mathrm{S}^{\mathrm{t}}$-Antoine vein. See Figure 4A for outcrops location.

Fig.6. Field and hand sample pictures of $\mathrm{Sb}$ and barren veins. (A) N22 ${ }^{\circ} \mathrm{E}$ striking subhorizontal slickenslide with chalcedonic and comb quartz with pyrite and arsenopyrite. A sinistral strike-slip movement can be inferred from kinematic criteria. (B) $\mathrm{N} 140^{\circ} \mathrm{E}$ striking subhorizontal slickenslide with chalcedonic and comb quartz with pyrite and arsenopyrite. The slickenslide indicates a sinistral strike-slip movement. (C) Reverse fault zone striking N85E, dipping $50^{\circ} \mathrm{S}$, with cataclasite and drag folds showing a top to the North shearing. (D) La Barbinière massive barren quartz vein. Subhorizontal slickenslide indicate a sinistral strike-slip movement with a normal component. See Figure 4 for outcrops location.

Fig.7. Microphotographs showing mineralogy of the initial scheelite infilling stage 1 to the gold stage (stage 2) of the la Bellière gold deposit paragenesis. Samples come from dumps of Bonair shaft (A to F) and from dumps of Verger shaft (photos G-H). (A) Weakly deformed plagioclase (Pl) and initial quartz (Qz1). The plagioclase is crosscut by a second quartz generation (Qz2) corresponding to neograins due to dynamic recrystallisation of the Qz1 during the shearing. Relic of Qz1 clasts are present in the upper right part of the photograph. (B) Initial quartz Qz1 highly sheared crosscut or in relic in the neoformed quartz (Qz2). (C) Large scheelite (Sch) grain crosscuted by galena (Gn), sphalerite (Sp), chalcopyrite (Ccp) veinlets. (D) SEM back-scattered electron image of apatite (Ap) crosscutting by galena (Gn) surrounded by iron dolomite (Dlo-Fe). (E) Relic of polysynthetic twin from an early plagioclase (Pl) in iron-bearing dolomite (Dol-Fe), and scheelite (Sch). This early paragenesis is crosscut by sphalerite (Sp), galena (Gn) and comb quartz (Qz3) veinlet belonging to the stage 2 paragenesis. (F) Scheelite (Sch) crosscut by fibrous quartz habitus (Qz3). (G) Detail of brecciated arsenopyrite crystal (Asp) cemented by fibrous quartz habitus with inclusion trails (Qz3). (H) Same microphotography as the previous one with a focus on the inclusion trails in the quartz Qz3. 
Fig.8. Microphotographs of ore minerals and their relationships with gangue quartz of the gold stage (stage 2). Samples come from dumps of St-Antoine shaft (photos A-B-C), from dumps of Verger shaft (photo D), Bonair shaft (photos E-FH). Sample from $\mathrm{G}$ microphotograph come from Bégrolle occurrence dump (see location in Fig. 3). (A) Clusters of fractured arsenopyrite (Asp) filled by sphalerite (Sp), electrum (El), galena (Gn) and chalcopyrite (Ccp). (B) Representative paragenesis of the main gold ore (stage 2) with clusters of arsenopyrite (Asp) fractured and filled by galena (Gn), electrum (El), sphalerite (Sp). (C) Cluster of fractured arsenopyrite (Asp) filled with sub-automorphous pyrite (Py) and chalcopyrite (Ccp). Pyrite (Py) includes electrum (El), sphalerite (Sp) and chalcopyrite (Ccp). Chalcopyrite (Ccp) also contains electrum (El) inclusions. (D) Sphalerite (Sp) with numerous micro-inclusions of chalcopyrite (Ccp). (E) High strain quartz gangue (Qz2) with numerous recrystallized grains and electrum (E1) located inside the highly deformed recrystallized quartz grains (Qz2). (F) SEM back-scattered electron image of galena (Gn) with ullmannite (Ull) inclusions. (G) SEM back-scattered electron image of galena (Gn) with bismuth-tellurides inclusions, hedleyite (Hed) and Bi-Pb-Ag sulphosalt. (H) Late stage 3 with microcrystalline quartz (Qz4) with illite (Ill) and pyrite-marcasite mixing (Py/Mar2), brecciated Qz1 and Qz2 quartz.

Fig.9. Paragenetic succession of the la Bellière gold deposit. See text for details.

Fig.10. Microphotographs of ore minerals and their relationships with gangue quartz deformation observed in Sb-bearing quartz veins. Samples have been collected on the $\mathrm{S}^{\mathrm{t}}$-Antoine vein striking N30 ${ }^{\circ} \mathrm{E}$ (photos, A-E) a N20 ${ }^{\circ} \mathrm{W}$ vein (photos, B-D), close to the $\mathrm{S}^{\mathrm{t}}$-Antoine vein and la Bertinière occurrences striking N20 $\mathrm{W}$ (photos, C-F-G) located in the eastern part of the district (Fig. 3). (A) Comb quartz veinlet with pyrite and marcasite (Py/Mar) and mosaic texture showing initial microcrystalline quartz (Qz1) acting as nucleus for the growth of fibro-radiated quartz (Qz2). (B) Initial filling of a microcrystalline quartz (Qz1) with no deformation surrounding by fibro-radiated quartz (Qz2) fractured and infilling with stibnite noted $\mathrm{Sb}$, (St-Antoine quartz vein). (C) SEM back-scattered electron image of arsenopyrite (Asp) encrusting pyrite-marcasite mixing note Py/Mar, (pseudomorph after early pyrrhotite note Po) and crystals with rhombic habitus. (D) Detail of a fibro-radiated quartz (Qz2) fractured and partially corroded by stibnite (Sb). (E) Stibnite (Sb) clusters with residual arsenopyrite (Asp). (F) Berthierite (Ber) and inclusions of chalcopyrite (Ccp) pseudomorphs by late stibnite (Sb). (G) Stibnite ( $\mathrm{Sb}$ ) with residual inclusions of berthierite (Ber) and native $\mathrm{Sb}$ (Sb-nat). (H) Stibnite (Sb) being replaced by late marcasite (Mar) and sphalerite (Sp).

Fig.11. Paragenetic succession of Sb-bearing chalcedonic and comb quartz veins. See text for details.

Fig.12. (A) Synthetic structural map of the la Bellière district with main mineralized quartz veins, mineralization occurrences, faults, and relative chronology. (B) Structural model showing two main deformation stages with (1) gold 
and (2) Sb deposition stages during the regional left-lateral strike-slip deformation. Z1-a corresponds to the interpreted maximum shortening direction, and probably the maximum principal stress direction during gold emplacement. Z1-b corresponds to the maximum shortening direction, interpreted as the maximum principal stress direction, during $\mathrm{Sb}$ deposition. The theoretical Riedel-shear model is from Wilcox et al. (1973).

Fig.13. Textural sketch showing the paragenetical evolution associated to deformation processes responsible for the formation of the La Bellière gold-bearing quartz vein. The early stage corresponds to the initial quartz vein filling with deposition of weakly deformed quartz gangue with plagioclase in high temperature conditions. During Stage 1, an important ductile/brittle deformation, coeval with arsenopyrite-pyrite and minor scheelite deposition, led to the early gold paragenetic stage under lithostatic pressure, and high temperature (around $430^{\circ} \mathrm{C}$ according to the arsenopyrite geothermometer). After this stage 1, a sharp P-T conditions decrease occurred in the hydrothermal system with a fast evolution to a more superficial and brittle deformation setting. This change was recorded by hydrostatic pressure as indicated by the crack-and-seal texture coeval with the deposition of economic gold stage 2 with base metal under at 300$250^{\circ} \mathrm{C}$ temperature conditions according to mineral paragenesis. Finally, the stage 3 was a late carbonate-microcrystalline quartz-pyrite-marcasite paragenesis (Py/Mar) that indicates the end of the hydrothermal system controlled by a temperature decrease from stage 2 .

Fig.14. Sketch illustrating the paragenesis evolution associated to deformation processes responsible for the formation of Sb-bearing quartz veins. Stage 1 is an early event of silification represented by brecciation of the country rock and development of microcrystalline vein filling with pyrrhotite. Stage 2 was a fracturing event that allowed the creation of voids into which deposition of fibro-radiated and comb quartz. This texture was coeval with pyrrhotite pseudomorph after pyrite and marcasite. Arsenopyrite encrusting developed under a relatively low temperature (ca; $\left.280-300^{\circ} \mathrm{C}\right)$. The final stage 3 was a reopening event that allowed the deposition of massive stibnite in open-space filling.

Table.1. Summary of EPMA analysis on arsenopyrite and comparison of the chemical composition. Estimated crystallization temperatures of arsenopyrite from gold-bearing quartz vein (la Bellière gold deposit) and Sb-bearing quartz vein ( $\mathrm{S}^{\mathrm{t}}$-Antoine vein and la Bertinière occurrences). The geothermometer is based on the projection of As activity (Kretschmar and Scott, 1976). 


\section{Declaration of interests}

$\bigotimes$ The authors declare that they have no known competing financial interests or personal relationships that could have appeared to influence the work reported in this paper.

$\square$ The authors declare the following financial interests/personal relationships which may be considered as potential competing interests:

\section{Highlights:}

- Study describes relationships between gold-bearing quartz veins and antimonybearing quartz veins in the French Armorican Massif.

- New structural, mineralogical and geochemical data are given.

- Two stage of emplacement are recorded with different structural control, gold bearing-quartz veins correspond to orogenic gold deposit emplaced under mesothermal environment, antimony quartz veins are shallower. 
- Chronologically gold event is emplaced during Visean age, while antimony event corresponds to Late Carboniferous metallogenic peak.

\section{Tables and appendices}

\section{Table 1}

\begin{tabular}{|c|c|c|c|c|c|c|c|c|c|c|c|c|c|c|c|}
\hline Samples & $\begin{array}{c}\text { Number of } \\
\text { analysis }\end{array}$ & S (W\%) & Std & $\mathrm{Fe}$ & Std & As & Std & Sb & Std & $\mathrm{Ni}$ & Std & Total & As (at\%) & Std & $\begin{array}{c}\mathrm{T}\left({ }^{\circ} \mathrm{C}\right) \\
\text { Kretsch } \\
\text { mar and } \\
\text { Scott, } \\
1976\end{array}$ \\
\hline Asp from la Bellière gold deposit & 13 & 20.71 & 0.22 & 34.97 & 0.60 & 44.24 & 0.36 & bdl & 0 & 0.17 & 0.46 & 100.09 & 31.66 & 0.31 & $430^{\circ} \mathrm{C}$ \\
\hline Asp from Sb occurrences (la Bellière district) & 30 & 20.86 & 0.32 & 34.32 & 0.39 & 38.97 & 1.61 & 4.75 & 1.71 & dl & 0 & 98.9 & 28.51 & 1.08 & $<300^{\circ} \mathrm{C}$ \\
\hline
\end{tabular}




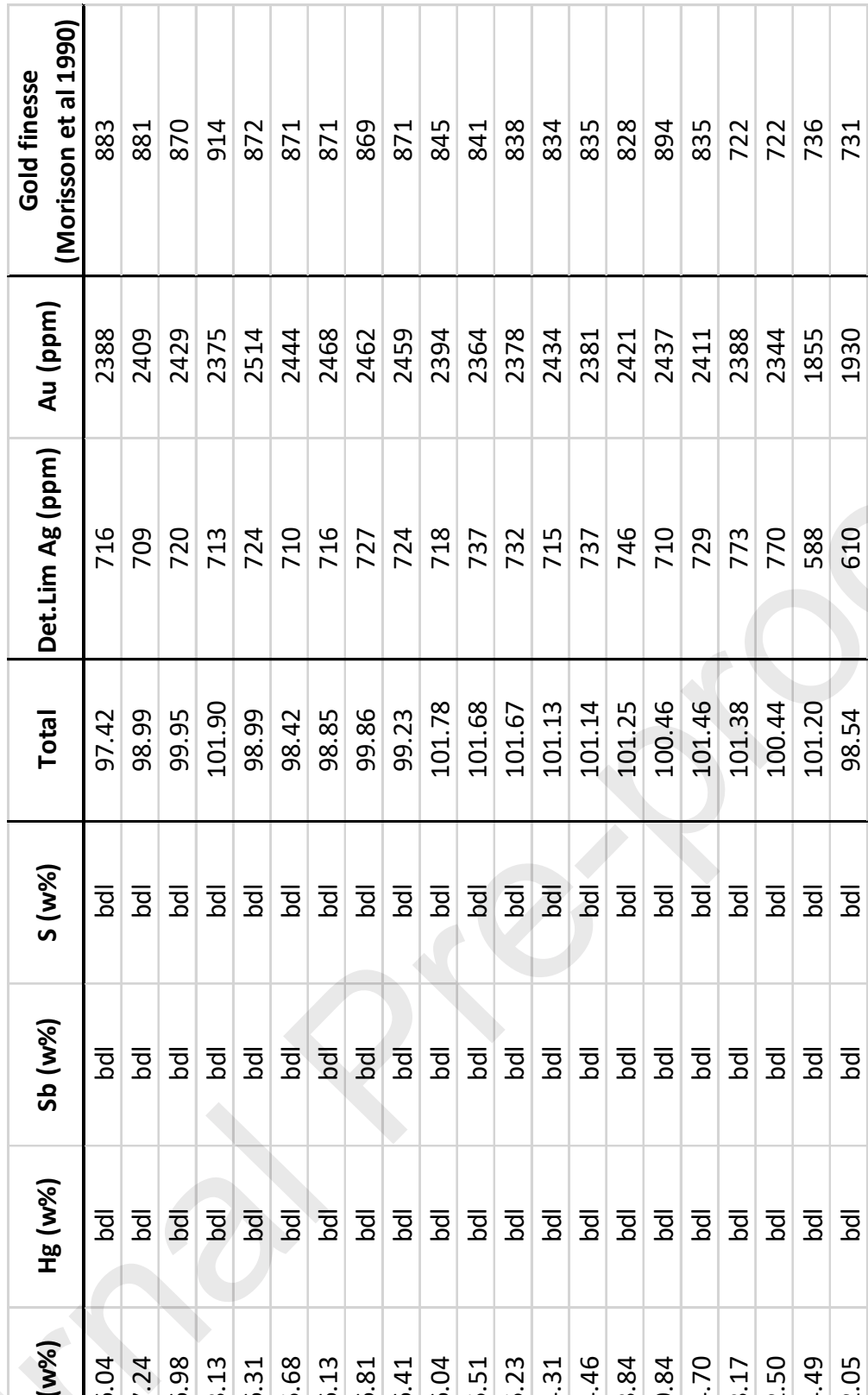
め

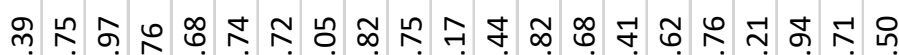
تี تُ

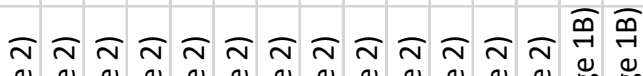

品

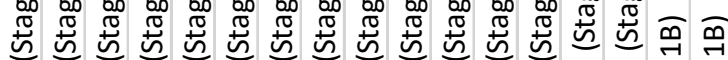

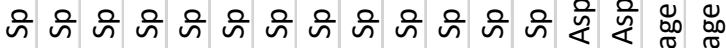

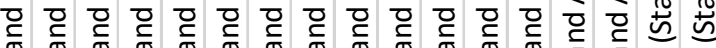

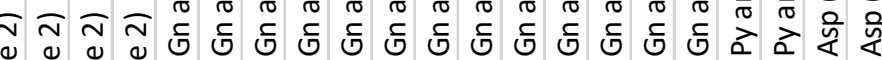

\$o

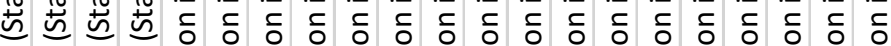

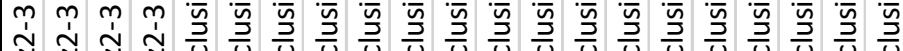

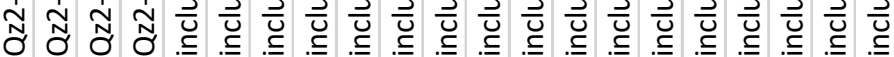

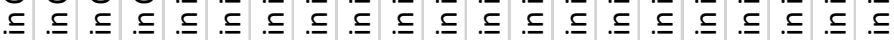

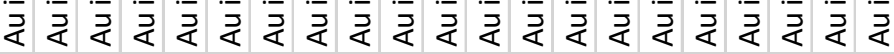

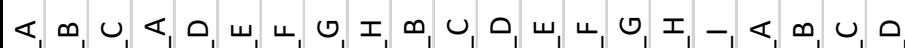

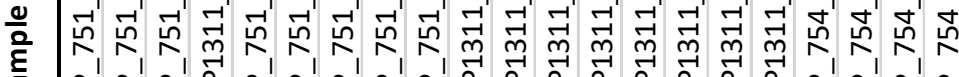




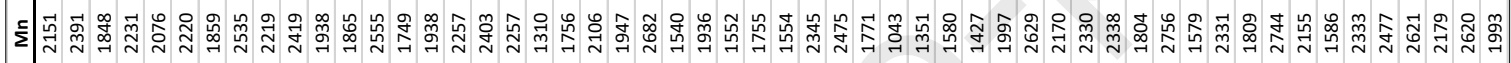

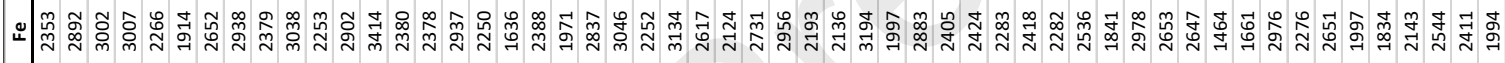

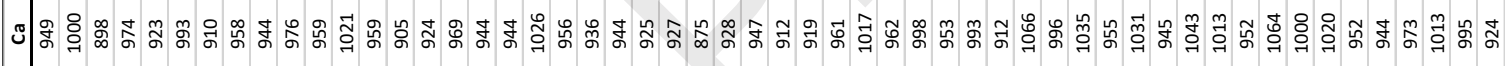

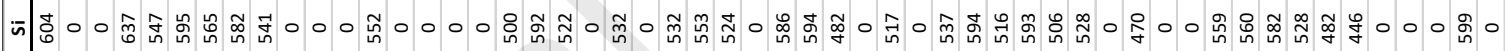

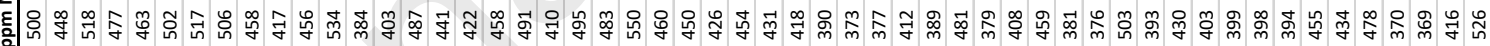

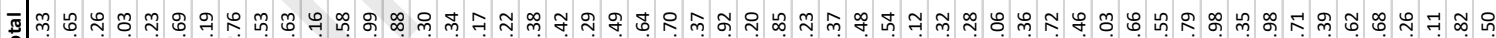

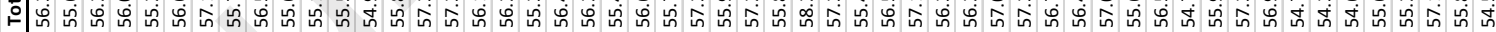

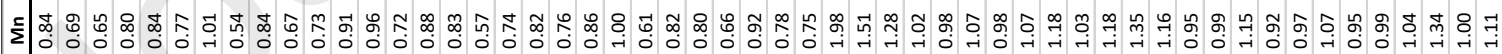

ڤ

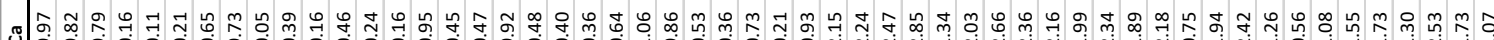

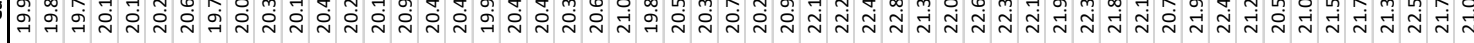

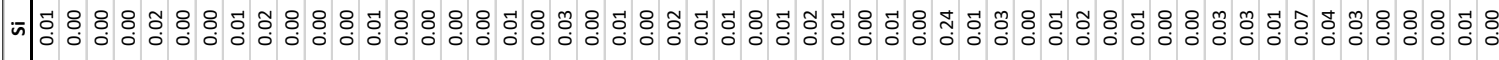

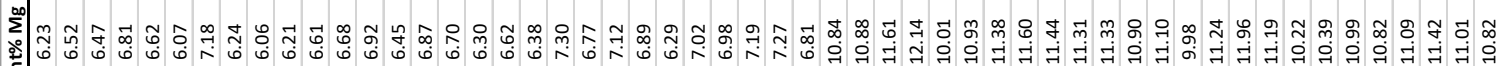

厄น

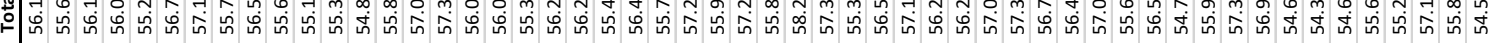

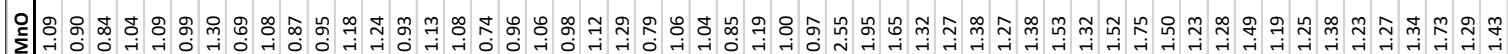




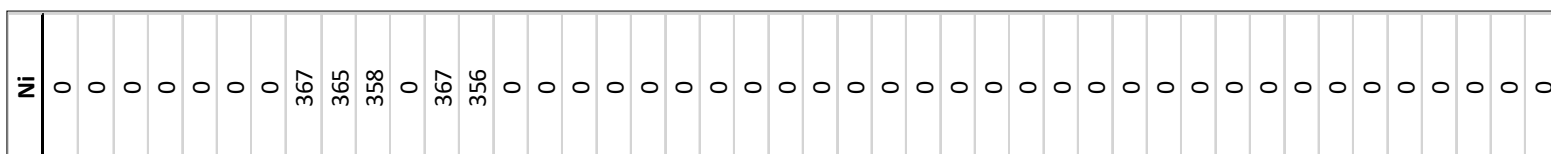

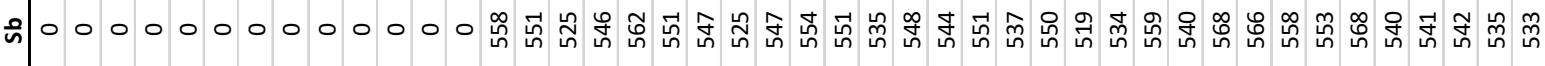

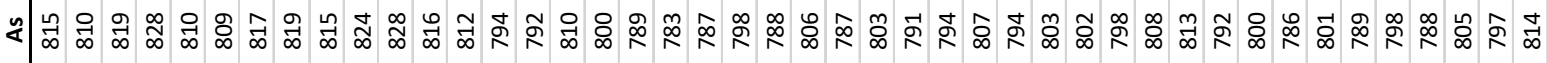

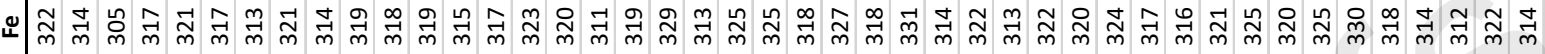

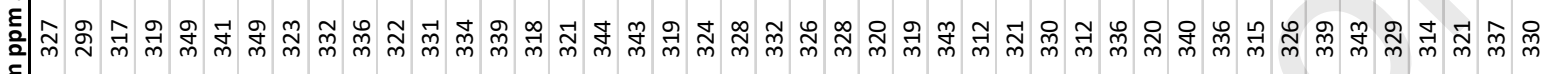

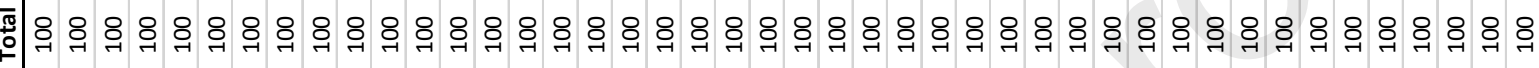

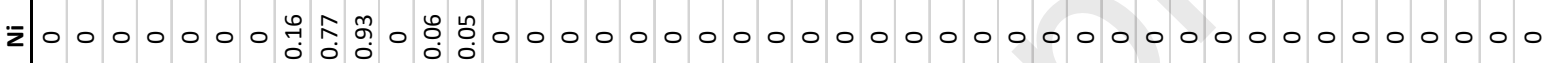

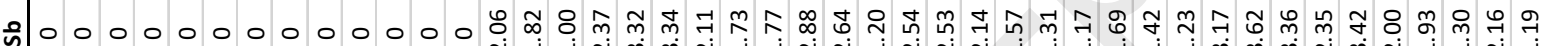

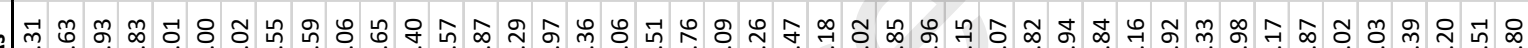

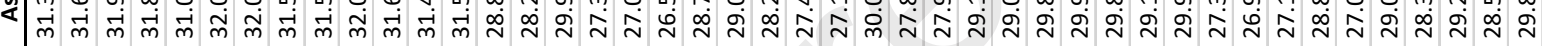

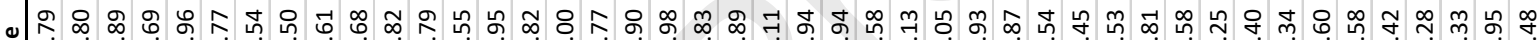

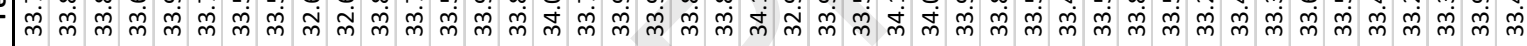

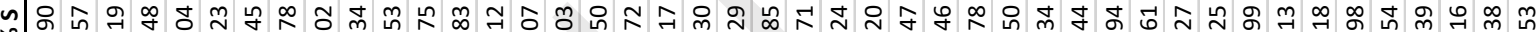

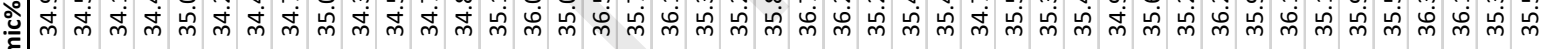

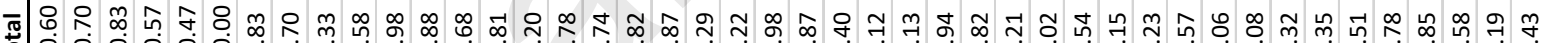

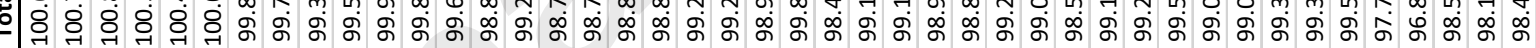

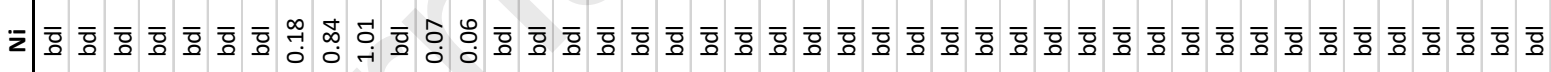

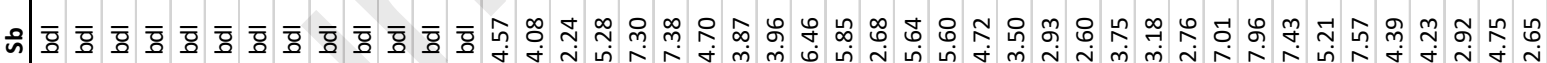
웅 ๖

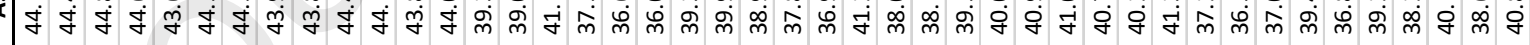

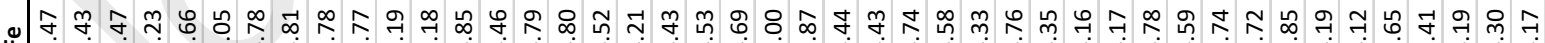

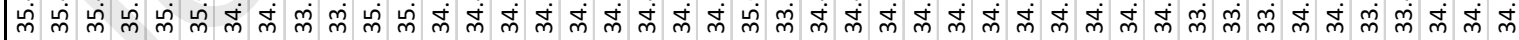

aํ.

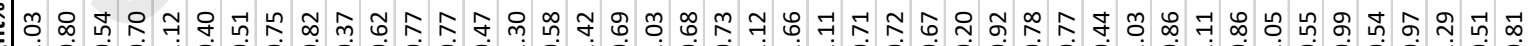

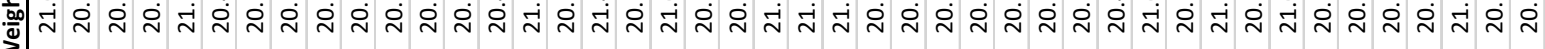

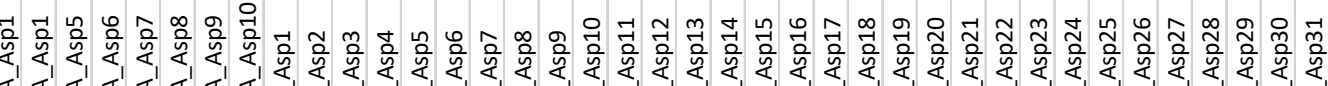

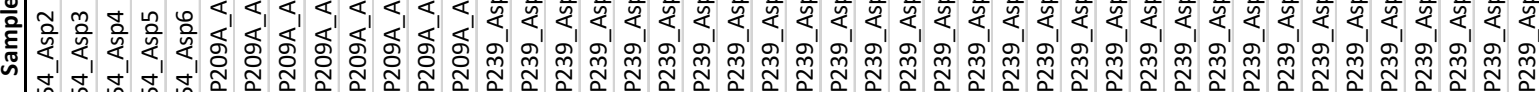

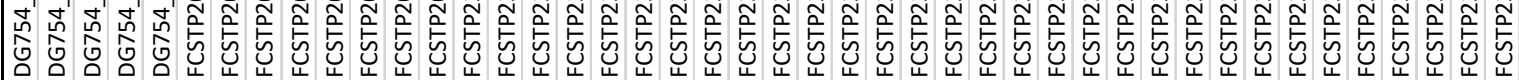

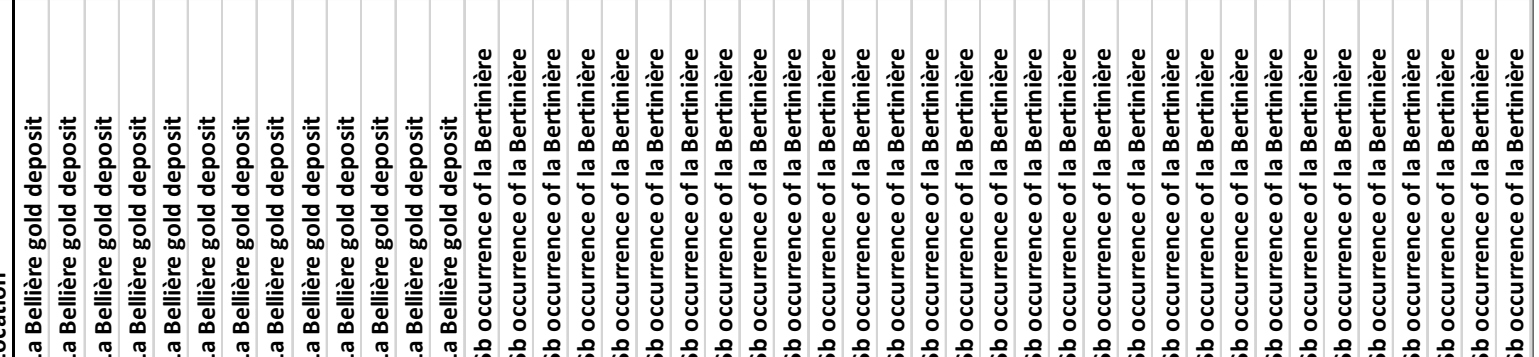


